\title{
Annona muricata (Annonaceae): A Review of Its Traditional Uses, Isolated Acetogenins and Biological Activities
}

\section{Soheil Zorofchian Moghadamtousi ${ }^{\mathbf{1}}$, Mehran Fadaeinasab ${ }^{\mathbf{2}}$, Sonia Nikzad ${ }^{\mathbf{1}}$, Gokula Mohan ${ }^{\mathbf{1}}$, Hapipah Mohd Ali ${ }^{2}$ and Habsah Abdul Kadir ${ }^{1, *}$}

1 Biomolecular Research Group, Biochemistry Program, Institute of Biological Sciences, Faculty of Science, University of Malaya, 50603 Kuala Lumpur, Malaysia; E-Mails: soheil.zorofchian@gmail.com (S.Z.M.); sonia.nikzad@gmail.com (S.N.); g.mohan@um.edu.my (G.M.)

2 Department of Chemistry, Faculty of Science, University of Malaya, 50603 Kuala Lumpur, Malaysia; E-Mails: mehranfadaei@um.edu.my (M.F.); hapipah@um.edu.my (H.M.A.)

* Author to whom correspondence should be addressed; E-Mail: habsah@um.edu.my; Tel.: +60-3-7967-4363; Fax: +60-3-7967-4178.

Academic Editor: Maurizio Battino

Received: 30 April 2015 / Accepted: 29 May 2015 / Published: 10 July 2015

\begin{abstract}
Annona muricata is a member of the Annonaceae family and is a fruit tree with a long history of traditional use. A. muricata, also known as soursop, graviola and guanabana, is an evergreen plant that is mostly distributed in tropical and subtropical regions of the world. The fruits of $A$. muricata are extensively used to prepare syrups, candies, beverages, ice creams and shakes. A wide array of ethnomedicinal activities is contributed to different parts of A. muricata, and indigenous communities in Africa and South America extensively use this plant in their folk medicine. Numerous investigations have substantiated these activities, including anticancer, anticonvulsant, anti-arthritic, antiparasitic, antimalarial, hepatoprotective and antidiabetic activities. Phytochemical studies reveal that annonaceous acetogenins are the major constituents of A. muricata. More than 100 annonaceous acetogenins have been isolated from leaves, barks, seeds, roots and fruits of $A$. muricata. In view of the immense studies on $A$. muricata, this review strives to unite available information regarding its phytochemistry, traditional uses and biological activities.
\end{abstract}


Keywords: Annona muricata; annonaceae; acetogenins; natural products; biological activity; bioactive compounds; fruit tree

\section{Introduction}

Natural products, especially those derived from plants, have been used to help mankind sustain its health since the dawn of medicine. Over the past century, the phytochemicals in plants have been a pivotal pipeline for pharmaceutical discovery. The importance of the active ingredients of plants in agriculture and medicine has stimulated significant scientific interest in the biological activities of these substances [1]. Despite these studies, a restricted range of plant species has experienced detailed scientific inspection, and our knowledge is comparatively insufficient concerning their potential role in nature. Hence, the attainment of a reasonable perception of natural products necessitates comprehensive investigations on the biological activities of these plants and their key phytochemicals [2]. In a pharmaceutical landscape, plants with a long history of use in ethno medicine are a rich source of active phytoconstituents that provide medicinal or health benefits against various ailments and diseases. One such plant with extensive traditional use is Annona muricata. In this review, we describe the botany, distribution and ethnomedicinal uses of this plant, and we summarize the phytochemistry, biological activities and possible mechanisms of $A$. muricata bioactivities.

\section{Botanical Description and Distribution}

A. muricata L., commonly known as soursop, graviola, guanabana, paw-paw and sirsak, is a member of the Annonaceae family comprising approximately 130 genera and 2300 species $[3,4]$. A. muricata is native to the warmest tropical areas in South and North America and is now widely distributed throughout tropical and subtropical parts of the world, including India, Malaysia and Nigeria [5]. A. muricata is an evergreen, terrestrial, erect tree reaching 5-8 $\mathrm{m}$ in height and features an open, roundish canopy with large, glossy, dark green leaves. The edible fruits of the tree are large, heart-shaped and green in color, and the diameter varies between 15 and $20 \mathrm{~cm}$ (Figure 1) [6].
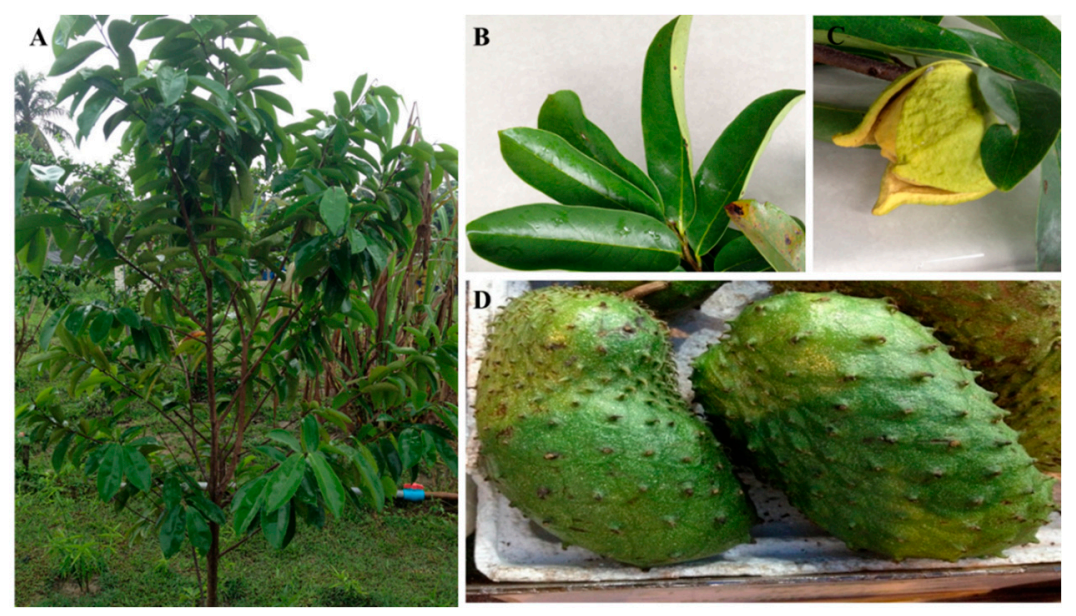

Figure 1. (A) Annona muricata L.; the appearance of the (B) leaves; (C) flowers and (D) fruits. 


\section{Ethnomedicinal Uses}

All portions of the A. muricata tree, similar to other Annona species, including A. squamosa and A. reticulata are extensively used as traditional medicines against an array of human ailments and diseases, especially cancer and parasitic infections. The fruit is used as natural medicine for arthritic pain, neuralgia, arthritis, diarrhea, dysentery, fever, malaria, parasites, rheumatism, skin rushes and worms, and it is also eaten to elevate a mother's milk after childbirth. The leaves are employed to treat cystitis, diabetes, headaches and insomnia. Moreover, internal administration of the leaf's decoction is believed to exhibit anti-rheumatic and neuralgic effects, whereas the cooked leaves are topically used to treat abscesses and rheumatism [3,5,7]. The crushed seeds are believed to have anthelmintic activities against external and internal worms and parasites. In tropical Africa, the plant is used as an astringent, insecticide and piscicide agent and to treat coughs, pain and skin diseases. In India, the fruit and flower are employed as remedies against catarrh, while the root-bark and leaves are believed to have antiphlogistic and anthelmintic activities [8,9]. In Malaysia, the crushed leaf mixture of A. muricata together with A. squamosa and Hibiscus rosa-sinensis is used as a juice on the head to protect against fainting [10]. In South America and tropical Africa, including Nigeria, leaves of A. muricata are deployed as an ethnomedicine against tumors and cancer [8]. In addition, the anti-inflammatory, hypoglycemic, sedative, smooth muscle relaxant, hypotensive and antispasmodic effects are also attributed to the leaves, barks and roots of A. muricata [3,5]. In addition to ethnomedicinal uses, the fruits are widely employed for the preparation of beverages, candy, ice creams, shakes and syrups $[11,12]$.

\section{Phytochemistry}

Extensive phytochemical evaluations on different parts of the A. muricata plant have shown the presence of various phytoconstituents and compounds, including alkaloids (ALKs) [4,13], megastigmanes (MGs) [14] flavonol triglycosides (FTGs) [15], phenolics (PLs) [16], cyclopeptides (CPs) and essential oils (Table 1, Figure 2) [17,18]. However, Annona species, including A. muricata, have been shown to be a generally rich source of annonaceous acetogenin compounds (AGEs) [19]. The presence of different major minerals such as $\mathrm{K}, \mathrm{Ca}, \mathrm{Na}, \mathrm{Cu}, \mathrm{Fe}$ and $\mathrm{Mg}$ suggest that regular consumption of the A. muricata fruit can help provide essential nutrients and elements to the human body [20]. 
Table 1. Chemical compounds isolated from Annona muricata. ALK: alkaloid; AGE: annonaceous acetogenin; MG: megastigmane; FTG: flavonol triglycoside; PL: phenolic; CP: cyclopeptide.

\begin{tabular}{|c|c|c|c|c|}
\hline Plant Part & Compound & Class & Biological Activity & References \\
\hline Fruits & annonaine & ALK & anti-depressive & {$[21,22]$} \\
\hline Fruits & nornuciferine & ALK & anti-depressive & {$[21,22]$} \\
\hline Fruits & asimilobine & ALK & anti-depressive & {$[21,22]$} \\
\hline Fruits & epomusenin-A & AGE & - & {$[23]$} \\
\hline Fruits & epomusenin-B & AGE & - & [23] \\
\hline Fruits & epomurinin-A & AGE & - & [23] \\
\hline Fruits & epomurinin-B & AGE & - & [23] \\
\hline Fruits & cis-annoreticuin & AGE & - & [24] \\
\hline Fruits & muricin $\mathrm{J}$ & AGE & toxicity against prostate PC-3 cancer cells & [25] \\
\hline Fruits & muricin $\mathrm{K}$ & AGE & toxicity against prostate $\mathrm{PC}-3$ cancer cells & [25] \\
\hline Fruits & muricin $\mathrm{L}$ & AGE & toxicity against prostate PC-3 cancer cells & [25] \\
\hline Fruits & cinnamic acid derivative & PL & - & {$[16]$} \\
\hline Fruits & coumaric acid hexose & PL & - & {$[16]$} \\
\hline Fruits & 5-caffeoylquinic acid & $\mathrm{PL}$ & - & {$[16]$} \\
\hline Fruits & dihydrokaempferol-hexoside & PL & - & {$[16]$} \\
\hline Fruits & $p$-coumaric acid & PL & - & {$[16]$} \\
\hline Fruits & caffeic acid derivative & $\mathrm{PL}$ & - & {$[16]$} \\
\hline Fruits & dicaffeoylquinic acid & $\mathrm{PL}$ & - & {$[16]$} \\
\hline Fruits & feruloylglycoside & PL & - & {$[16]$} \\
\hline Fruits & 4-feruloyl-5-caffeoylquinic acid & $\mathrm{PL}$ & - & {$[16]$} \\
\hline Fruits & $p$-coumaric acid methyl ester & PL & - & {$[16]$} \\
\hline $\begin{array}{l}\text { Leaves, } \\
\text { Pericarp }\end{array}$ & annomuricin A & AGE & $\begin{array}{l}\text { toxicity against brine shrimp, lung A549, } \\
\text { breast MCF- } 7 \text { and colon HT-29 cancer cells }\end{array}$ & {$[12,26]$} \\
\hline Leaves & annomuricin B & AGE & $\begin{array}{l}\text { toxicity against brine shrimp, lung A549, } \\
\text { breast MCF-7 and colon HT-29 cancer cells }\end{array}$ & {$[12]$} \\
\hline Leaves & annomuricin $\mathrm{C}$ & AGE & $\begin{array}{l}\text { toxicity against brine shrimp, lung A549, } \\
\text { breast MCF- } 7 \text { and colon HT-29 cancer cells }\end{array}$ & [27] \\
\hline Leaves & annomuricin $\mathrm{E}$ & AGE & $\begin{array}{c}\text { toxicity against pancreatic MIA PaCa-2 } \\
\text { and colon HT-29 cancer cells }\end{array}$ & [28] \\
\hline Leaves & annomutacin & AGE & toxicity against lung A549 cancer cells & [29] \\
\hline Leaves & $(2,4-c i s)-10 R$-annonacin-A-one & AGE & toxicity against lung A549 cancer cells & [29] \\
\hline Leaves & $(2,4$-trans $)$-10R-annonacin-A-one & AGE & toxicity against lung A549 cancer cells & [29] \\
\hline Leaves & annohexocin & AGE & $\begin{array}{c}\text { toxicity against brine shrimp } \\
\text { and different cancer cells }\end{array}$ & {$[30]$} \\
\hline Leaves & muricapentocin & AGE & $\begin{array}{c}\text { toxicity against pancreatic MIA PaCa-2 } \\
\text { and colon HT-29 cancer cells } \\
\end{array}$ & [28] \\
\hline Leaves & $(2,4-c i s)$-isoannonacin & AGE & - & {$[31]$} \\
\hline Leaves, Seeds & $(2,4-$ trans $)$-isoannonacin & AGE & - & {$[31,32]$} \\
\hline Leaves & muricatocin $\mathrm{A}$ & AGE & toxicity against lung A549 cancer cells & [31] \\
\hline Leaves & muricatocin $\mathrm{B}$ & AGE & toxicity against lung A549 cancer cells & {$[31]$} \\
\hline
\end{tabular}


Table 1. Cont.

\begin{tabular}{|c|c|c|c|c|}
\hline Plant Part & Compound & Class & Biological Activity & References \\
\hline Leaves & muricatocin $\mathrm{C}$ & AGE & $\begin{array}{c}\text { toxicity against brine shrimp, } \\
\text { lung A549, breast MCF-7 and colon } \\
\text { HT-29 cancer cells }\end{array}$ & [27] \\
\hline Leaves, Seeds & gigantetronenin & AGE & - & {$[27,32]$} \\
\hline $\begin{array}{c}\text { Leaves, Seeds, } \\
\text { Pericarp } \\
\end{array}$ & annonacin $\mathrm{A}$ & AGE & - & {$[26,31,33]$} \\
\hline Leaves & annopentocin $\mathrm{A}$ & AGE & $\begin{array}{l}\text { toxicity against pancreatic } \\
\text { MIA PaCa-2 cancer cells }\end{array}$ & [34] \\
\hline Leaves & annopentocin B & AGE & toxicity against lung A549 cancer cells & [34] \\
\hline Leaves & annopentocin $\mathrm{C}$ & AGE & toxicity against lung A549 cancer cells & [34] \\
\hline Leaves & cis-annomuricin-D-one & AGE & $\begin{array}{l}\text { toxicity against lung A549, colon HT-29 } \\
\text { and pancreatic MIA PaCa-2 cancer cells }\end{array}$ & [34] \\
\hline Leaves & trans-annomuricin-D-one & AGE & $\begin{array}{l}\text { toxicity against lung A549, colon HT-29 } \\
\text { and pancreatic MIA PaCa- } 2 \text { cancer cells }\end{array}$ & [34] \\
\hline Leaves & murihexocin A & AGE & toxicity against different cancer cells & [35] \\
\hline Leaves & murihexocin $\mathrm{B}$ & AGE & toxicity against different cancer cells & [35] \\
\hline Leaves & murihexocin $\mathrm{C}$ & AGE & toxicity against different cancer cells & [36] \\
\hline Leaves & muricoreacin & AGE & toxicity against different cancer cells & {$[36]$} \\
\hline Leaves & cis-corossolone & AGE & toxicity against human hepatoma cells & [37] \\
\hline Leaves & annocatalin & AGE & toxicity against human hepatoma cells & [37] \\
\hline Leaves & annocatacin B & AGE & toxicity against human hepatoma cells & {$[38]$} \\
\hline Leaves & anonaine & ALK & neurotoxic & {$[39,40]$} \\
\hline Leaves & isolaureline & ALK & - & [39] \\
\hline Leaves & xylopine & ALK & - & [39] \\
\hline Leaves & $\begin{array}{l}\text { Quercetin 3-O- } \alpha \text {-rhamnosyl- } \\
\quad(1 \rightarrow 6) \text { - } \beta \text {-sophoroside } \\
\end{array}$ & FTG & - & [15] \\
\hline Leaves & gallic acid & FTG & - & {$[15]$} \\
\hline Leaves & epicatechine & FTG & - & {$[15]$} \\
\hline Leaves & quercetin 3-O-rutinosid & FTG & - & {$[15]$} \\
\hline Leaves & quercetin 3-O-neohispredoside & FTG & - & [15] \\
\hline Leaves & quercetin 3-O-robinoside & FTG & - & [15] \\
\hline Leaves & catechine & FTG & - & {$[15]$} \\
\hline Leaves & chlorogenic acid & FTG & - & {$[15]$} \\
\hline Leaves & $\begin{array}{c}\text { argentinine (1-N,N- } \\
\text { dimethylethanyl-4,6-dimethoxy- } \\
\text { 3,8-dihydroxy-phenanthrene) }\end{array}$ & FTG & - & {$[15]$} \\
\hline Leaves & kaempferol 3-O-rutinoside & FTG & - & [15] \\
\hline Leaves & quercetin 3-O-glucoside & FTG & - & {$[15]$} \\
\hline Leaves & quercetin & FTG & - & {$[15]$} \\
\hline Leaves & kaempferol & FTG & - & {$[15]$} \\
\hline Leaves & annonamine & ALK & - & [40] \\
\hline Leaves & $(S)$-norcorydine & ALK & - & [40] \\
\hline
\end{tabular}


Table 1. Cont.

\begin{tabular}{|c|c|c|c|c|}
\hline Plant Part & Compound & Class & Biological Activity & References \\
\hline Leaves & $(R)-4^{\prime}-O$-methylcoclaurine & ALK & - & {$[40]$} \\
\hline Leaves & $(R)$-O,O-dimethylcoclaurine & ALK & - & [40] \\
\hline Leaves & annoionol A & MG & - & [14] \\
\hline Leaves & annoionol B & MG & - & {$[14]$} \\
\hline Leaves & annoionol $\mathrm{C}$ & MG & - & {$[14]$} \\
\hline Leaves & annoionoside & MG & - & {$[14]$} \\
\hline Leaves & vomifoliol & MG & - & {$[14]$} \\
\hline Leaves & roseoside & MG & - & {$[14]$} \\
\hline Leaves & turpinionoside $\mathrm{A}$ & MG & - & {$[14]$} \\
\hline Leaves & citroside $\mathrm{A}$ & MG & - & {$[14]$} \\
\hline Leaves & blumenol C & MG & - & {$[14]$} \\
\hline Leaves & $(+)$-epiloliolide & MG & - & {$[14]$} \\
\hline Leaves & loliolide & MG & - & {$[14]$} \\
\hline Leaves & $\begin{array}{c}(1 S, 2 S, 4 R) \text {-trans-2-hydroxy-1,8- } \\
\text { cineole } \beta \text {-D-glucopyranoside }\end{array}$ & MG & - & [14] \\
\hline Leaves & $\begin{array}{l}\text { (Z)-3-hexenyl } \beta \text {-D- } \\
\text { glucopyranoside }\end{array}$ & MG & - & {$[14]$} \\
\hline Leaves & rutin & MG & - & {$[14]$} \\
\hline Leaves & kaempferol 3-O-rutinoside & MG & - & {$[14]$} \\
\hline Leaves & kaempferol 3-O-robinobioside & MG & - & {$[14]$} \\
\hline Leaves & $\begin{array}{c}\text { kaempferol 3-O- } \beta-\mathrm{D}-\left(2^{\prime \prime}-O-\beta-\mathrm{D}-\right. \\
\text { glucopyranosyl, } 6 \text { "'-O- } \alpha-\mathrm{L}- \\
\text { rhamnopyranosyl)glucopyranoside }\end{array}$ & MG & - & [14] \\
\hline Roots & montecristin & AGE & - & [41] \\
\hline Roots & cohibin A & AGE & - & {$[42]$} \\
\hline Roots & cohibin B & AGE & - & [42] \\
\hline Roots & cis-solamin & AGE & - & [43] \\
\hline Roots & cis-panatellin & AGE & - & [43] \\
\hline Roots & cis-uvariamicin IV & AGE & - & [43] \\
\hline Roots & cis-uvariamicin I & AGE & - & [43] \\
\hline Roots & cis-reticulatacin & AGE & - & [43] \\
\hline Roots & cis-reticulatacin-10-one & AGE & - & [43] \\
\hline Roots & chatenaytrienin 1 & AGE & - & [44] \\
\hline Roots & chatenaytrienin 2 & AGE & - & [44] \\
\hline Roots & chatenaytrienin 3 & AGE & - & [44] \\
\hline Roots & muridienin 3 & AGE & - & [44] \\
\hline Roots & muridienin 4 & AGE & - & [44] \\
\hline Roots & muricadienin & AGE & - & [44] \\
\hline Roots & coronin & AGE & - & {$[45]$} \\
\hline Roots, Fruits & sabadelin & AGE & - & {$[24,46]$} \\
\hline Seeds & murisolin & AGE & - & {$[47]$} \\
\hline Seeds & muricatacin & AGE & $\begin{array}{l}\text { toxicity against lung A549, breast MCF7, } \\
\text { colon HT-29 cancer cells }\end{array}$ & [48] \\
\hline
\end{tabular}


Table 1. Cont.

\begin{tabular}{|c|c|c|c|c|}
\hline Plant Part & Compound & Class & Biological Activity & References \\
\hline $\begin{array}{l}\text { Seeds, Leaves, } \\
\text { Pericarp }\end{array}$ & annonacin & AGE & $\begin{array}{l}\text { neurotoxic, molluscicidal, inhibitor of } \\
\text { mitochondrial complex I }\end{array}$ & {$[12,26,48-51]$} \\
\hline Seeds, Leaves & corossolone & AGE & $\begin{array}{c}\text { toxicity against oral } \mathrm{KB} \text { cancer cells and } \\
\text { brine shrimp larva, antileishmanial }\end{array}$ & {$[37,52-54]$} \\
\hline Seeds & corossolin & AGE & $\begin{array}{c}\text { toxicity against oral } \mathrm{KB} \text { cancer cells and } \\
\text { brine shrimp larva }\end{array}$ & {$[52]$} \\
\hline $\begin{array}{l}\text { Seeds, Roots, } \\
\text { Leaves }\end{array}$ & solamin & AGE & $\begin{array}{c}\text { toxicity against oral KB cancer and } \\
\text { normal kidney VERO cells }\end{array}$ & {$[37,43,55]$} \\
\hline Seeds & corepoxylone & AGE & - & [56] \\
\hline Seeds, Leaves & annonacin-10-one & AGE & - & {$[12,57]$} \\
\hline Seeds & isoannonacin & AGE & molluscicidal, anticancer & {$[49,57]$} \\
\hline Seeds & isoannonacin-10-one & AGE & - & [57] \\
\hline Seeds, Leaves & goniothalamicin & AGE & molluscicidal & {$[12,49,57]$} \\
\hline Seeds & gigantetrocin & AGE & - & [57] \\
\hline Seeds, Leaves & gigantetrocin $\mathrm{A}$ & AGE & $\begin{array}{c}\text { toxicity against colon HT-29 cancer } \\
\text { cells }\end{array}$ & {$[12,32,58]$} \\
\hline Seeds & gigantetrocin B & AGE & $\begin{array}{l}\text { toxicity against colon HT-29 cancer } \\
\text { cells }\end{array}$ & {$[12,32,58]$} \\
\hline Seeds, Leaves & muricatetrocin A & AGE & $\begin{array}{l}\text { toxicity against colon HT-29 cancer } \\
\text { cells }\end{array}$ & {$[58]$} \\
\hline Seeds, Leaves & muricatetrocin B & AGE & $\begin{array}{l}\text { toxicity against colon HT-29 cancer } \\
\text { cells }\end{array}$ & [58] \\
\hline Seeds, Leaves & epomuricenin A & AGE & - & {$[23,59]$} \\
\hline Seeds, Leaves & epomuricenin B & AGE & - & {$[23,59]$} \\
\hline Seeds & annomuricatin A & $\mathrm{CP}$ & - & {$[60,61]$} \\
\hline Seeds & annocatacin A & AGE & toxicity against human hepatoma cells & {$[38]$} \\
\hline Seeds & annomuricatin $\mathrm{C}$ & $\mathrm{CP}$ & - & [62] \\
\hline Seeds & cis-annonacin & AGE & $\begin{array}{l}\text { crown gall tumor inhibition, toxicity } \\
\text { against brine shrimp, lung A549, breast } \\
\text { MCF-7 and colon HT-29 cancer cells }\end{array}$ & [63] \\
\hline Seeds & cis-annonacin-10-one & AGE & $\begin{array}{l}\text { crown gall tumor inhibition, toxicity } \\
\text { against brine shrimp, lung A549, breast } \\
\text { MCF-7 and colon HT-29 cancer cells }\end{array}$ & [63] \\
\hline Seeds & cis-goniothalamicin & AGE & $\begin{array}{l}\text { crown gall tumor inhibition, toxicity } \\
\text { against brine shrimp, lung A549, breast } \\
\text { MCF-7 and colon HT-29 cancer cells }\end{array}$ & [63] \\
\hline Seeds & arianacin & AGE & $\begin{array}{l}\text { crown gall tumor inhibition, toxicity } \\
\text { against brine shrimp, lung A549, breast } \\
\text { MCF-7 and colon HT-29 cancer cells }\end{array}$ & [63] \\
\hline Seeds & javoricin & AGE & $\begin{array}{l}\text { crown gall tumor inhibition, toxicity } \\
\text { against brine shrimp, A549, breast } \\
\text { MCF-7 and colon HT- } 29 \text { cancer cells }\end{array}$ & [63] \\
\hline Seeds & murihexol & AGE & - & [33] \\
\hline
\end{tabular}


Table 1. Cont.

\begin{tabular}{|c|c|c|c|c|}
\hline Plant Part & Compound & Class & Biological Activity & References \\
\hline Seeds & donhexocin & AGE & - & [33] \\
\hline Seeds & cohibin C & AGE & - & [64] \\
\hline Seeds & cohibin D & AGE & - & {$[64]$} \\
\hline Seeds & muricatenol & AGE & - & {$[32,65]$} \\
\hline Seeds & 2,4-cis-gigantetrocinone & AGE & - & {$[32]$} \\
\hline Seeds & 2,4-trans-gigantetrocinone & AGE & - & [32] \\
\hline Seeds & 2,4-trans-isoannonacin-10-one & AGE & - & {$[32]$} \\
\hline Seeds & annomontacin & AGE & - & [32] \\
\hline Seeds & longifolicin & AGE & toxicity against human hepatoma cells & [66] \\
\hline Seeds & muricin $\mathrm{A}$ & AGE & toxicity against human hepatoma cells & {$[66]$} \\
\hline Seeds & muricin $\mathrm{B}$ & AGE & toxicity against human hepatoma cells & [66] \\
\hline Seeds & muricin $\mathrm{C}$ & AGE & toxicity against human hepatoma cells & [66] \\
\hline Seeds & muricin $\mathrm{D}$ & AGE & toxicity against human hepatoma cells & {$[66]$} \\
\hline Seeds & muricin $\mathrm{E}$ & AGE & toxicity against human hepatoma cells & [66] \\
\hline Seeds & muricin $\mathrm{F}$ & AGE & toxicity against human hepatoma cells & [66] \\
\hline Seeds & muricin $\mathrm{G}$ & AGE & toxicity against human hepatoma cells & {$[66]$} \\
\hline Seeds & muricin $\mathrm{H}$ & AGE & toxicity against human hepatoma cells & {$[37]$} \\
\hline Seeds & muricin I & AGE & toxicity against human hepatoma cells & [37] \\
\hline Seeds & cis-annomontacin & AGE & toxicity against human hepatoma cells & [37] \\
\hline Seeds, Leaves & annonacinone & AGE & - & [37] \\
\hline Seeds & xylomaticin & AGE & - & {$[37]$} \\
\hline Seeds & $N$-fatty acyl tryptamines & ALK & - & {$[32]$} \\
\hline Seeds & annoreticuin-9-one & AGE & - & [24] \\
\hline Stem barks & epoxymurin A & AGE & - & [67] \\
\hline Stem barks & epoxymurin B & AGE & - & {$[67]$} \\
\hline $\begin{array}{c}\text { Leaves, Roots, } \\
\text { Stems, Barks }\end{array}$ & reticuline & ALK & - & {$[68]$} \\
\hline $\begin{array}{l}\text { Leaves, Roots, } \\
\text { Stems, Barks }\end{array}$ & coclaurine & ALK & - & {$[68]$} \\
\hline $\begin{array}{c}\text { Leaves, Roots, } \\
\text { Stems, Barks }\end{array}$ & coreximine & ALK & - & {$[68]$} \\
\hline $\begin{array}{c}\text { Leaves, Roots, } \\
\text { Stems, Barks }\end{array}$ & atherosperminine & ALK & - & {$[68]$} \\
\hline $\begin{array}{c}\text { Leaves, Roots, } \\
\text { Stems, Barks }\end{array}$ & stepharine & ALK & - & {$[68]$} \\
\hline $\begin{array}{l}\text { Leaves, Roots, } \\
\text { Stems, Barks }\end{array}$ & anomurine & ALK & - & {$[68]$} \\
\hline $\begin{array}{c}\text { Leaves, Roots, } \\
\text { Stems, Barks }\end{array}$ & anomuricine & ALK & - & {$[68]$} \\
\hline
\end{tabular}


<smiles>COc1ccc(C[C@H]2c3cc(O)c(OC)cc3CCN2C)cc1O</smiles>

reticuline<smiles>COc1ccc2cc(C(O)CN(C)C)c3ccccc3c2c1</smiles>

atherosperminine<smiles>COc1ccc(CC2NCCc3c2cc(OC)c(OC)c3O)cc1</smiles>

anomuricine<smiles>COc1c(O)cc2c3c1-c1ccccc1C[C@H]3NCC2</smiles>

asimilobine<smiles>COc1cc2c(cc1O)[C@H](Cc1ccc(O)cc1)NCC2</smiles>

coclaurine<smiles>COc1cc2c3c(c1OC)CC1(C=CC(=O)C=C1)[C@H]3NCC2</smiles>

stepharine<smiles>c1ccc2c(c1)C[C@@H]1NCCc3cc4c(c(c3-2)OCO4)N1</smiles>

annonaine<smiles>COc1cc2c(cc1O)C1Cc3cc(O)c(O)cc3CN1CC2</smiles>

coreximine<smiles>COc1ccc(C[C@H]2NCCc3c2cc(OC)c(OC)c3OC)cc1</smiles><smiles>COc1cc2c3c(c1OC)-c1cc4c(cc1C[C@H]4NCC3)OCO2</smiles>

nornuciferine

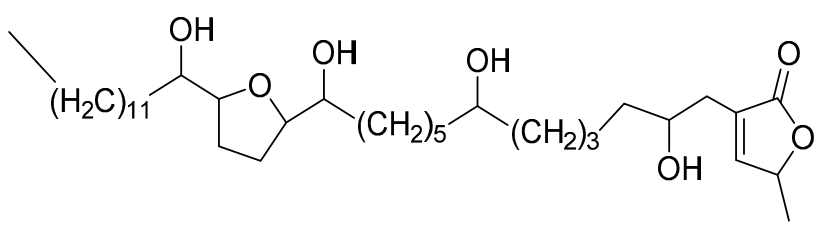

cis-annoreticuin

Figure 2. Cont. 


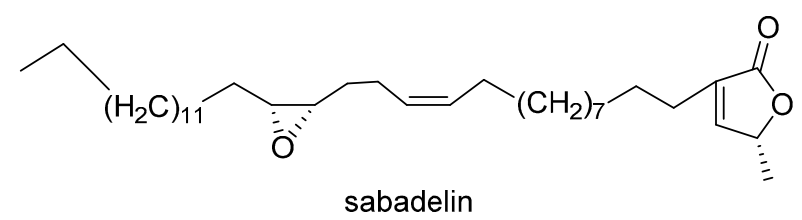<smiles>CCCCCCCCCCCCC(O)C(O)C(O)CCCCCC(O)CC1=CC(C)OC1=O</smiles>

annomuricin $\mathrm{A}$<smiles>CC[CH][C@@H](O)[C@@H]1CCC(O)([C@@H](O)CCC[C@H](O)[C@@H](O)CCCCCCCCC)O1</smiles>

annomuricin B

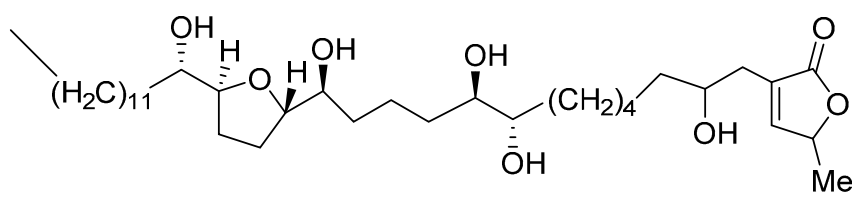
annomuricin $\mathrm{E}$

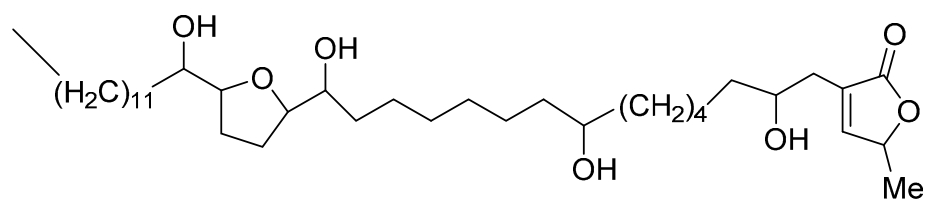
annomutacin

Figure 2. Cont. 
Int. J. Mol. Sci. 2015, 16
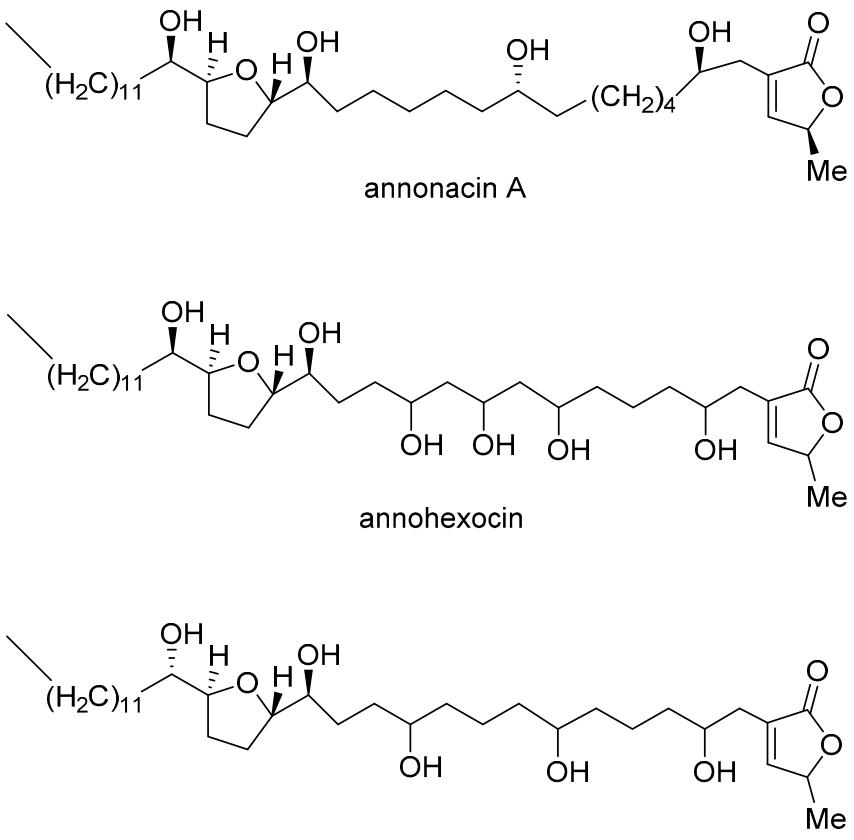

muricapentocin
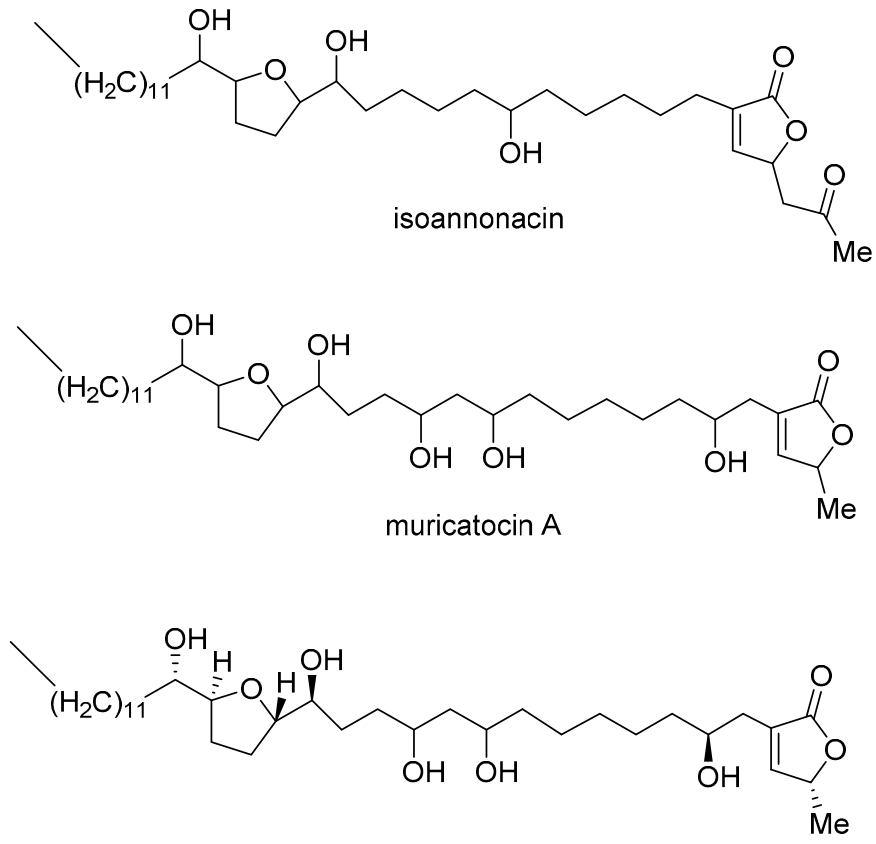

muricatocin $\mathrm{B}$

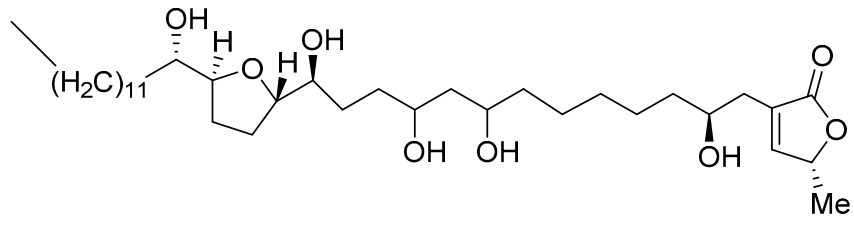

muricatocin $\mathrm{C}$

Figure 2. Cont. 
Int. J. Mol. Sci. 2015, 16

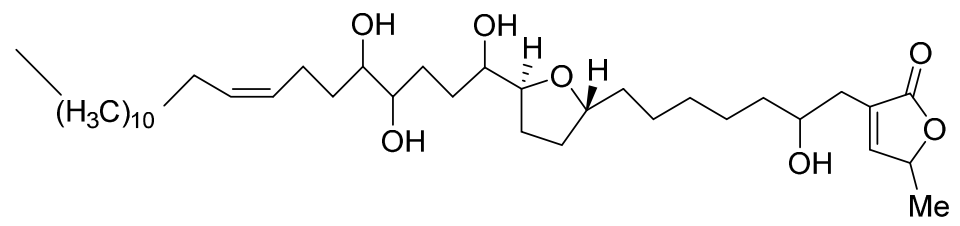

gigantetronenin

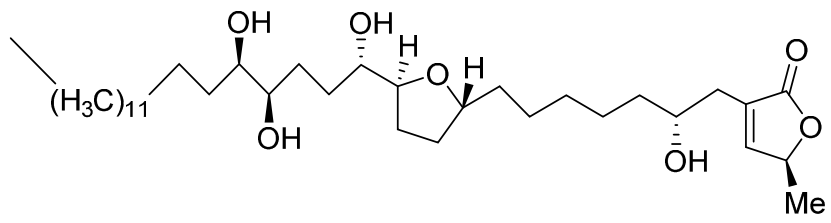

gigantetrocin $\mathrm{A}$

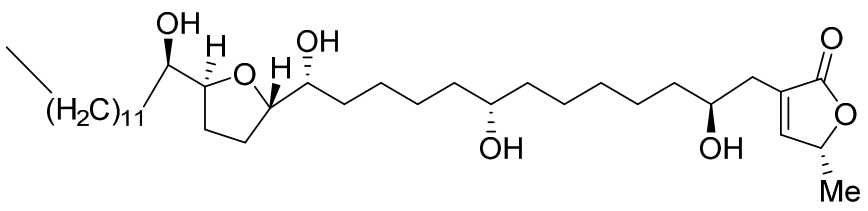

annonacin $\mathrm{A}$<smiles>CC(C)[C@H](O)[C@H](O)CC[C@H](O)[C@@H]1CC[C@@H]([C@H](O)CCCCC[C@H](O)CC2=C[C@H](C)OC2=O)O1</smiles>

annopentocin $\mathrm{A}$<smiles>CC(C)[C@@H](O)[C@H](O)CC[C@@H](O)[C@H]1CC[C@@H]([C@H](O)CCCCC[C@H](O)CC2=C[C@H](C)OC2=O)O1</smiles>

annopentocin B<smiles>CC(C)[C@H](O)[C@H](O)CC[C@@H](O)[C@@H]1CC[C@H]([C@H](O)CCCCC[C@H](O)CC2=C[C@H](C)OC2=O)O1</smiles>

annopentocin C

Figure 2. Cont. 


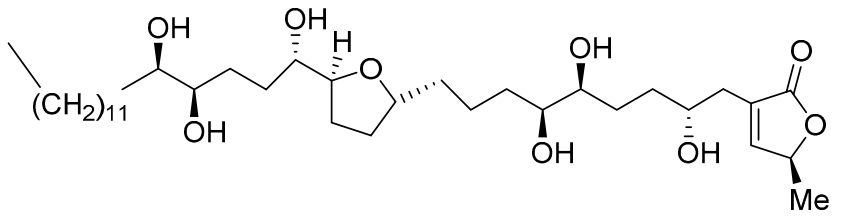

murihexocin A

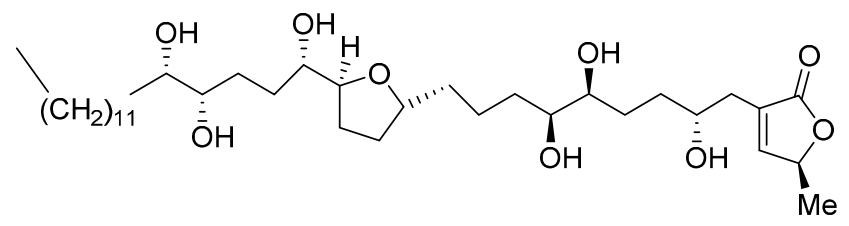

murihexocin $\mathrm{B}$

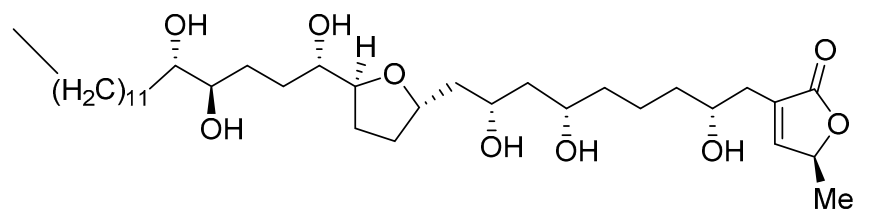

muricoreacin

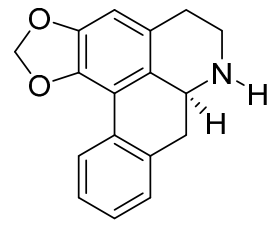

anonaine<smiles>CC(O)CC[C@H]1[C@@H](C)[C@H](O)[C@@H](O)CC1(C)C</smiles>

annoionol $\mathrm{A}$<smiles>[CH]O[C@H]1[C@@H](O)C[C@](C)(O)[C@@](O)(/C=C/[C@H](C)O)[C@@H]1C</smiles>

annoionoside

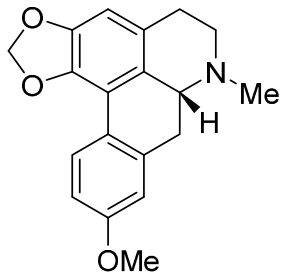

isolaureline<smiles>CC(O)/C=C/C1(O)[C@@H](C)[C@@H](O)[C@@H](O)C[C@]1(C)O</smiles>

annoionol B<smiles>CC1=CC(=O)C[C@](C)(O)[C@]1(C)/C=C/[C@H](C)O</smiles>

vomifoliol<smiles>COc1ccc2c(c1)CC1NCCC3=CC4=C(OCO4)C3=C21</smiles>

xylopine<smiles>C[C@H](O)CC[C@H]1[C@@H](CO)C[C@@H](O)CC1(C)C</smiles>

annoionol C<smiles>CC1=CC(=O)C[C@](C)(O)[C@]1(C)/C=C/[C@H](C)O[Na]</smiles>

roseoside

Figure 2. Cont. 
<smiles>C[C@H](O)/C=C/[C@@]1(O)[C@@H](C)C[C@@H](OC2CCCCC2)C[C@]1(C)O</smiles>

turpinionoside $\mathrm{A}$<smiles>C=C1C=C2C(C)(C)C[C@H](O)C[C@@]2(C)O1</smiles>

(+)-epiloliolide<smiles>CC(=O)C=C=C1C(C)(C)C[C@H](O)C[C@]1(C)Cl</smiles>

citroside A

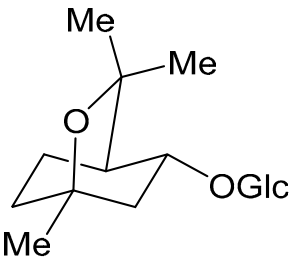

(1S,2S,4R)-trans-2-hydroxy-1,8-cineole d-glucopyranoside<smiles>C[C@H]1O[C@H](O[C@@H]2O[C@H](OC3=C(c4ccc(O)cc4)OC4C=C(O)C=C(O)C4C3=O)[C@@H](O)[C@H](O)[C@@H]2O)[C@H](O)[C@@H](O)[C@@H]1O</smiles>

kaempferol 3-O-rutinoside<smiles>CC1=CC(=O)CC(C)(C)[C@H]1CC[C@H](C)O</smiles>

blumenol C

(Z)-3-hexenyl -d-glucopyranoside<smiles>O=C1C(OC2OC(O[C@@H]3O[C@H](O)[C@H](O)[C@H](O)[C@H]3O)[C@@H](O)[C@H](O)[C@H]2O)=C(c2ccc(O)cc2)OC2C=C(O)C=C(O)C12</smiles>

kaempferol 3-O-robinobioside<smiles>CCCCCCC1=CC(C)OC1=O</smiles>

montecristin<smiles>C[AlH]CCC=CCCC(O)C(O)CCCC1=CC(C)OC1=O</smiles>

cohibin A

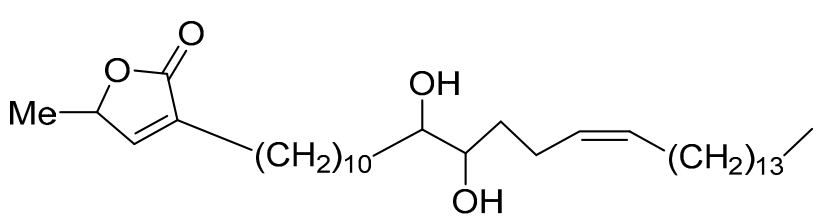

cohibin B<smiles>[H][Y20]([H])(CC1=CC(C)OC1=O)C(O)C1CCC(C(O)C[AlH]C)O1</smiles>

cis-solamin

Figure 2. Cont. 


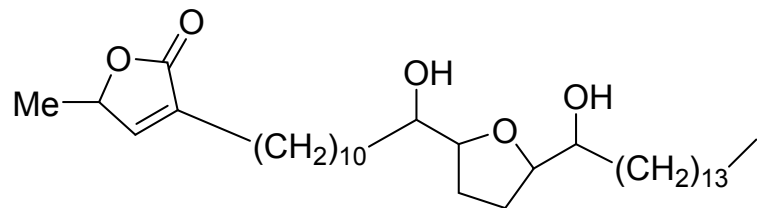

cis-panatellin

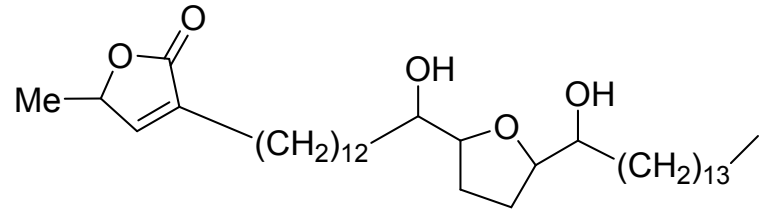
cis-uvariamicin I<smiles>CCC1=CC(C)OC1=O</smiles>
cis-reticulatacin-10-one

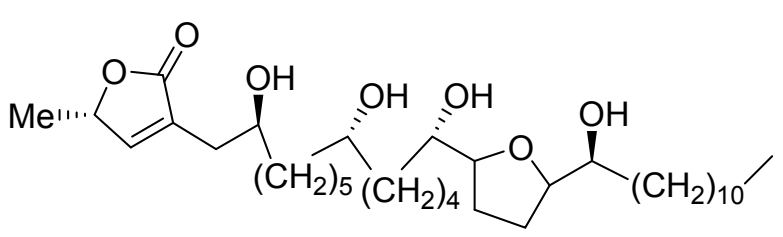
annonacin<smiles>C[AlH]CCC1=C[C@@H](C)OC1=O</smiles>
corossolin<smiles>C[14CH2]C[C@H](O)[C@@H]1CC[C@H]([C@H](O)CC(=O)CCC2=C[C@@H](C)OC2=O)O1</smiles>
annonacin-10-one<smiles>C[15CH2]CC(O)C1CCC(C(O)OCCC2=CC(C)OC2=O)O1</smiles>

cis-uvariamicin IV

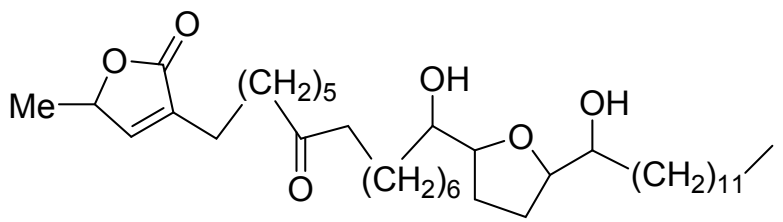

cis-reticulatacin<smiles>CCC(O)C1CCC(=O)O1</smiles>

muricatacin<smiles>C[14CH2]CC1=C[C@@H](C)OC1=O</smiles>
corossolone<smiles>C[14CH2]C[C@H](O)[C@@H]1CC[C@@H]([C@@H](O)CC2=C[C@@H](C)OC2=O)O1</smiles>
solamin

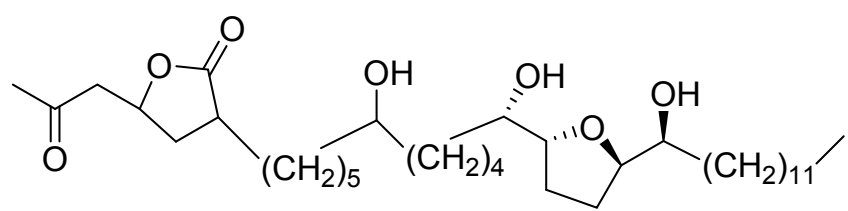
isoannonacin

Figure 2. Cont. 
<smiles>CCCCCCCCC[C@@H](O)[C@@H]1CC[C@@H]([C@H](O)CC(O)CCCCCC)O1</smiles>

goniothalamicin<smiles>C[13CH2][13CH2][C@H](O)CC1CC(C)OC1=O</smiles>

gigantetrocin<smiles>C[13CH2][13CH2][C@H](O)CC1C[C@H](C)OC1=O</smiles>
gigantetrocin A<smiles>C/C=C/CC1OC1CCCCC1OC1CCC1CC(C)OC1=O</smiles>

epomuricenin $\mathrm{A}$<smiles>C[InH]C[C@H](O)[C@@H]1CC[C@H]([C@@H](O)CC(O)CCC(C)CC2=C(C)COC2=O)O1</smiles>

cis-annonacin<smiles>CC(O)CC1=CC(C)OC1=O</smiles>

cis-goniothalamicin

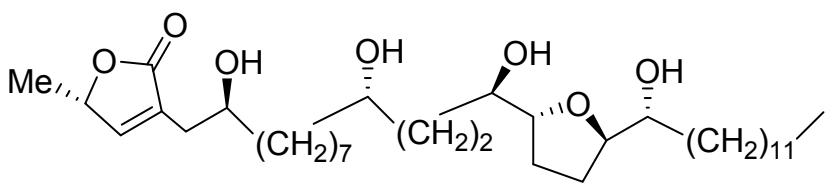
javoricin

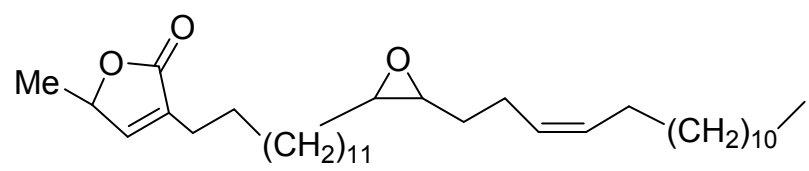
epoxymurin A

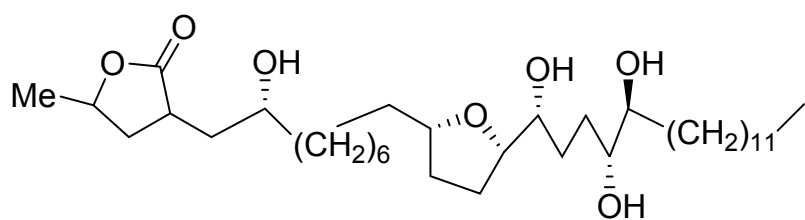
muricatetrocin A

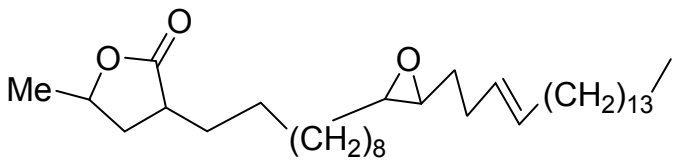

epomuricenin B<smiles>CC1=C(CC(O)CCCCCC(=O)C[C@H](O)[C@@H]2CC[C@@H]([C@@H](O)C[InH2])O2)C(=O)OC1</smiles>
cis-annonacin-10-one

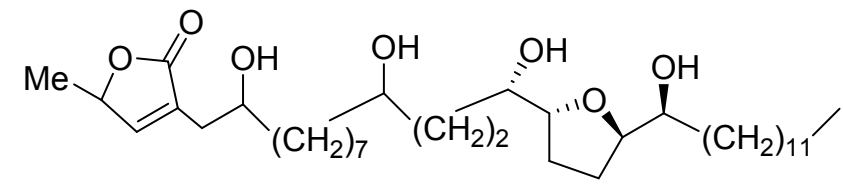
arianacin<smiles>C[AlH][C](C)[C@H](O)[C@@H]1CC[C@@H]([C@H](O)CC(=O)CC[C@H](O)CC2=CC(C)OC2=O)O1</smiles>
annoreticuin-9-one

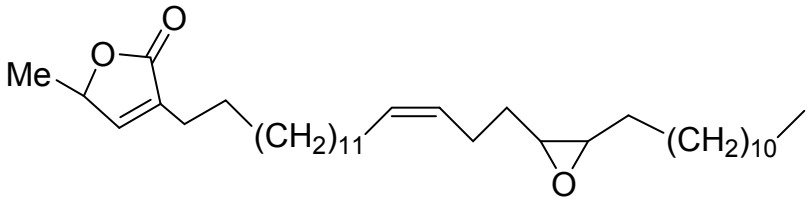
epoxymurin B

Figure 2. Chemical structures of the major compounds isolated from Annona muricata. 


\subsection{Essential Oil}

GC and GC-MS analyses on the leaf oil of $A$. muricata collected from Cameroon showed the presence of mostly sesquiterpenes, with the major compound present being $\beta$-caryophyllene [69]. Another study on $A$. muricata collected from Vietnam identified significant volatile oil constituents of $\beta$-pinene (20.6\%), germacrene D (18.1\%), $\rho$-mentha-2,4(8)-diene (9.8\%), $\alpha$-pinene (9.4\%) and $\beta$-elemene (9.1\%) from the leaf oil [70]. The compounds of $\delta$-cadinene, epi- $\alpha$-cadinol and $\alpha$-cadinol are also other major compounds reportedly found in the leaf oil extracts [18]. The fruit pulp essential oil was found to have esters of aliphatic acids with major compounds of 2-hexenoic acid methyl ester and 2-hexenoic acid ethyl ester. However, high concentrations of mono- and sesquiterpenes, including $\beta$-caryophyllene, 1,8-cineole and linalool, were also isolated from the fruit pulp [71].

\subsection{Annonaceous Acetogenins}

AGEs are a unique class of C-35/C37 secondary metabolites derived from long chain (C-32/C34) fatty acids in the polyketide pathway. They are usually characterized by a combination of fatty acids with a 2-propanol unit at C-2 that forms a methyl-substituted $\alpha, \beta$-unsaturated $\gamma$-lactone [72]. Since the discovery of uvaricin from Uvaria accuminata in 1982, more than 500 AGEs have been identified from different parts of the plants in the Annonaceae family [73,74]. Due to the special structures and extensive biological activities, AGEs have attracted significant scientific interest in recent years. Various biological activities have been reported for AGEs, including antimalarial, antiparasitic and pesticidal activities [72,75]. However, the biological activities of AGEs are primarily characterized with toxicity against cancer cells and inhibitory effects against the mitochondrial complex I (mitochondrial NADH: ubiquinone oxidoreductase) [76,77]. Phytochemical investigations and biological studies on different parts of the A. muricata plant resulted in the identification of a wide array of AGE compounds, as summarized in Table 1. The chemical structures of the major acetogenins are shown in Figure 2. To the best of our knowledge, at the time of preparation (January 2015) of the present review over 100 AGEs have been identified in A. muricata.

\section{Biological Activities}

\subsection{Anti-Arthritic Activity}

A. muricata is among the ethnomedicines employed to treat arthritic pain. An in vivo study on different doses $(3,10,30$ and $100 \mathrm{mg} / \mathrm{kg}$ ) of ethanolic extract from A. muricata leaves has investigated the anti-arthritic activity in complete Freund's adjuvant (CFA)-induced arthritis in rats. According to the results, oral administration of the extract reduced the edema in a dose-dependent manner after two weeks of injection. Because the extract at higher doses significantly suppressed TNF- $\alpha$ and IL-1 $\beta$ expression in local tissue, the anti-arthritic activity of $A$. muricata leaves contributed to the suppression of pro-inflammatory cytokines [78]. Hence, the anti-arthritic potential of A. muricata was substantiated by the findings of this in vivo study. 


\subsection{Anticancer Activity}

Plenty of studies report the significant antiproliferative effects of different extracts of the plant and isolated AGEs towards various cancer cell lines [26,79-82]; however, few of these studies have illustrated the underlying mechanism of action (Table 2). Recent in vitro studies were performed by our research group to determine the mechanism of action of ethyl acetate extract of $A$. muricata leaves against colon cancer cells (HT-29 and HCT-116) and lung cancer cells (A549). The leaf extract was able to induce apoptosis in colon and lung cancer cells through the mitochondrial-mediated pathway. This antiproliferative effect was associated with cell cycle arrest in the $\mathrm{G}_{1}$ phase [83,84]. In addition, the migration and invasion of colon cancer cells were significantly inhibited by the leaf extract. The activation of caspase 3 by the ethanolic extract of the leaves also demonstrated an apoptosis-inducing effect in myelogenous leukemic K562 cells, which was confirmed with a TUNEL assay [85].

Table 2. Anticancer studies on A. muricata.

\begin{tabular}{|c|c|c|c|}
\hline Plant Part & Subject of Study & Effect & Reference \\
\hline $\begin{array}{l}\text { ethyl acetate extract } \\
\text { of the leaves }\end{array}$ & lung A549 cancer cells & $\begin{array}{l}\text { mitochondrial-mediated apoptosis, } \\
\text { cell cycle arrest at } \mathrm{G}_{1} \text { phase }\end{array}$ & {$[83]$} \\
\hline $\begin{array}{l}\text { ethyl acetate extract } \\
\text { of the leaves }\end{array}$ & $\begin{array}{c}\text { colon } \mathrm{HT}-29 \text { and } \\
\text { HCT-116 cancer cells }\end{array}$ & $\begin{array}{l}\text { mitochondrial-mediated apoptosis, cell cycle arrest } \\
\text { at } G_{1} \text { phase, suppression of migration and invasion }\end{array}$ & {$[84]$} \\
\hline $\begin{array}{l}\text { water extract } \\
\text { of the leaves }\end{array}$ & rat's prostate & reduction of prostate size & {$[86]$} \\
\hline $\begin{array}{l}\text { ethanolic extract of } \\
\text { the leaves }\end{array}$ & breast tissues of mice & prevention of DMBA-induced DNA damage & {$[87]$} \\
\hline $\begin{array}{c}\text { ethanolic extract } \\
\text { of the leaves }\end{array}$ & $\begin{array}{l}\text { DMBA/croton oil induced } \\
\text { mice skin papillomagenesis }\end{array}$ & suppression of tumor initiation and promotion & {$[88]$} \\
\hline $\begin{array}{c}\text { ethanolic extract } \\
\text { of the leaves }\end{array}$ & DMH induced colon cancer & reduction of $\mathrm{ACF}$ formation & [89] \\
\hline $\begin{array}{c}\text { ethanolic extract } \\
\text { of the leaves }\end{array}$ & $\begin{array}{l}\text { K562 chronic myeloid } \\
\text { leukemia cells }\end{array}$ & induction of apoptosis & {$[85]$} \\
\hline leaves boiled in water & metastatic breast cancer & stabilization of disease & {$[90]$} \\
\hline $\begin{array}{l}\text { ethyl acetate } \\
\text { of the leaves }\end{array}$ & $\begin{array}{l}\text { azoxymethane induced } \\
\text { colon cancer }\end{array}$ & reduction of $\mathrm{ACF}$ formation & {$[91]$} \\
\hline $\begin{array}{l}\text { ethyl acetate } \\
\text { of the leaves }\end{array}$ & colon HT-29 cancer cells & $\begin{array}{l}\text { bioassay-guided isolation of annomuricin E } \\
\text { and its apoptosis inducing effect }\end{array}$ & [91] \\
\hline
\end{tabular}

Recent in vitro and in vivo studies were performed on the water extract of the A. muricata leaves against the benign prostatic hyperplasia (BPH-1) cell line and rats' prostates. The results showed a suppressive effect on BPH-1 cells with an $\mathrm{IC}_{50}$ value of $1.36 \mathrm{mg} / \mathrm{mL}$ after $72 \mathrm{~h}$ associated with an up-regulation of Bax and a down-regulation of Bcl-2 at the mRNA level. After two months of treatment with the extract (30 and $300 \mathrm{mg} / \mathrm{mL}$ doses), the size of the rats' prostates were decreased, which was suggested to occur through apoptosis induction [86]. This promising antitumor effect also reported in an in vivo study on 7,12-dimethylbenzene anthracene (DMBA)-induced cell proliferation in the breast tissues of mice. The protective effect against DNA damage induced by DMBA showed that oral administration of the $A$. muricata leaves may have protective effects towards the development of breast 
carcinogenesis [87]. The leaves, even at the low dose of $30 \mathrm{mg} / \mathrm{kg}$ suppressed the initiation and promotion stage of skin papillomagenesis in mice that was induced by DMBA and croton oil, respectively [88].

Moghadamtousi and colleagues [91] also examined the in vivo chemopreventive potential of the ethyl acetate extract of the A. muricata leaves against azoxymethane-induced colonic aberrant crypt foci $(\mathrm{ACF})$ in rats. The oral administration of the extract at two doses $(250$ and $500 \mathrm{mg} / \mathrm{kg}$ ) for 60 days significantly reduced ACF formation in rats, as assessed by methylene blue staining of colorectal specimens. The immunohistochemistry analysis showed that this activity was accompanied by the up-regulation of Bax and the down-regulation of Bcl-2. This significant reduction in ACF formation was also reported for the ethanolic extract of the leaves against 1,2-dimethyl hydrazine (DMH)-induced colon cancer [89]. Our study was followed by an in vitro bioassay-guided investigation against HT-29 cells, which led to the isolation of annomuricin E. This AGE showed mitochondrial-dependent apoptosis activity in colon cancer cells with an $\mathrm{IC}_{50}$ value of $1.62 \pm 0.24 \mu \mathrm{g} / \mathrm{mL}$ after $48 \mathrm{~h}$ [91].

Anticancer studies on A. muricata were not only limited to in vitro and in vivo investigations. A case study of a 66-year old woman with a metastatic breast cancer reported that consumption of the leaves boiled in water and Xeloda resulted in stabilization of the disease [90]. These substantial anticancer and antitumor activities mentioned for A. muricata leaves led to tablet formulations of the ethyl acetate-soluble fraction of the leaves, which contains AGEs that can be used as a cancer adjuvant therapy [92].

\subsection{Anticonvulsant Activity}

In African countries, the decoction of the A. muricata leaves is traditionally used to control fever and convulsive seizures [93]. To substantiate the anticonvulsant activity of the leaves in ethnomedicine, Gouemo and colleagues [93] investigated the effect of the ethanolic extract of the leaves against pentylenetetrazol-induced tonic-clonic seizures in mice. The result showed that the plant extract at 100 and $300 \mathrm{mg} / \mathrm{kg}$ doses significantly decreased the incidence and the mortality rate of tonic seizures. Administration of the extract to mice also lengthened the onset of clonic seizures. This study showed that a subsequent bioassay-guided investigation may lead to the isolation of a bioactive compound that can be used as an anticonvulsant drug.

\subsection{Antidiabetic and Hypolipidemic Activity}

The chronic disease of diabetes mellitus afflicts a large proportion of people all around the world. Therefore, an effective natural adjuvant therapy would be blindingly beneficial to diminish diabetic complications and augment the quality of life for diabetic patients. Due to the traditional application of A. muricata against diabetes, several studies have investigated this potential in vivo. Adeyemi and colleagues [94] reported that daily intraperitoneal injection of streptozotocin-induced diabetic Wistar rats with the methanol extract of $A$. muricata leaves $(100 \mathrm{mg} / \mathrm{kg})$ for two weeks significantly reduced their blood glucose concentration from 21.64 to $4.22 \mathrm{mmol} / \mathrm{L}$ [94]. In addition, the extract at the same dose significantly decreased the serum total cholesterol, low-density lipoprotein, triglyceride and very low-density lipoprotein cholesterol [95]. 
Based on the ethnopharmacological application of $A$. muricata leaves against diabetes in Cameroon, another similar study examined the aqueous extract of the leaves against streptozotocin-induced diabetes in rats and reported the same promising antidiabetic activities. This activity was explained by its antioxidant and hypolipidemic potentials and protective effects against pancreatic $\beta$-cells [96]. Histopathological examination showed that the leaf extract caused the regeneration of $\beta$-cells in the pancreas islets [5,97]. The stem bark ethanolic extract also demonstrated promising antidiabetic and hypolipidemic activities against alloxan- induced diabetic rats. Treatment with the extract (150 and $300 \mathrm{mg} / \mathrm{kg}$ ) to rats for 14 days lowered the increased blood glucose and was associated with a reduction in cholesterol and triglyceride levels [98].

\subsection{Anti-Inflammatory and Anti-Nociceptive Activities}

Oral treatment in rats with $A$. muricata ethanolic leaf extracts $(10,30,100$ and $300 \mathrm{mg} / \mathrm{kg})$ significantly reduced carrageenan-induced edema in rat paws by $79 \%$ in a dose-dependent manner, exhibiting its anti-inflammatory activities [99]. This anti-inflammatory effect was accompanied by reductions in the leukocyte migration and exudate volume [7]. Oral administration in mice with the same extract showed significant suppression of abdominal contortions induced with acetic acid $(0.6 \% v / v)$, exhibiting a powerful anti-nociceptive activity $[99,100]$. In addition, the formalin test and paw licking and hot-plate responses also corroborated the marked analgesic effect of the $A$. muricata leaves $[7,99,100]$. The protective effect of the A. muricata leaves against Complete Freund's adjuvant (CFA)-induced arthritis in rats and xylene-induced ear edema in mice was associated with an attenuation in the TNF- $\alpha$ and IL-1 $\beta$ protein expression, demonstrating that the leaves could be used against both acute and chronic inflammation [100]. The same assays showed the anti-inflammatory and analgesic activities for the $A$. muricata fruits, which were shown to be induced through the suppression of inflammatory mediators and interactions with the opioidergic pathway, respectively [101]. These findings demonstrated the anti-nociceptive and anti-inflammatory effects of $A$. muricata and substantiated its traditional consumption as pain killer.

\subsection{Antioxidant Activity}

Immoderate generation of intracellular reactive oxygen species (ROS) is a precursor of oxidative stress which subsequently catalyzes metabolic deficiency and cellular death through biochemical and physiological lesions [102]. The identification of antioxidants from natural products has become a matter of great interest in recent studies for their noteworthy role in nullifying the destructive effects of ROS [103,104]. DRSA, FRAP and HRSA tests on aqueous and methanolic leaf extracts of $A$. muricata revealed the marked antioxidative activities of both extracts accompanied with DNA protective effects against $\mathrm{H}_{2} \mathrm{O}_{2}$-induced toxicity [105]. The antioxidant activity of the $A$. muricata leaves was found to be stronger than $A$. squamosa and $A$. reticulata species as shown through different in vitro models, such as ABTS, nitric oxide and hydroxyl radicals [106]. The seeds and leaves of the plant are reported to possess enzymatic antioxidants, including catalase and superoxide dismutase, and non-enzymatic antioxidants, including vitamin C and E [107]. Padma and colleagues showed that the ethanolic extract of the A. muricata stem bark caused a reduction in lipid peroxidation induced by cold immobilization stress in the brain and liver of rats, indicating the adaptogenic potential of this plant $[108,109]$. The stem bark 
extract $(200 \mathrm{mg} / \mathrm{kg})$ also showed protective effects against oxidative stress induced by carbon tetrachloride in rats and significantly increased the oxidant levels and serum enzyme activities to near normal. The DPPH test showed the antioxidant activity of the stem bark [110]. These findings strongly suggest the potential use of $A$. muricata as a natural source of antioxidants.

\subsection{Antihypertensive Activity}

To evaluate the antihypertensive properties of $A$. muricata leaves, aqueous leaf extract $(9.17-48.5 \mathrm{mg} / \mathrm{kg})$ was administered to normotensive Sprague-Dawley rats. The results demonstrated that treatments of rats with the leaf extract significantly decreased blood pressure in a dose-dependent manner without affecting heart rates. This effect was suggested to be induced through peripheral mechanisms involving the antagonism of $\mathrm{Ca}^{2+}[111]$.

\subsection{Antiparasitic Activity}

Protozoal infections cause debilitating diseases, such as leishmaniasis and trypanosomiasis, which have both afflicted a noteworthy proportion of the world population. The development of resistance to empirically discovered drugs represents a major hindrance to treatment of protozoal diseases. Moreover, in case of long-term usage, toxicity and several side effects have made the available treatments more unsatisfactory. As a natural agent, A. muricata has been subjected to various pathogenic parasites to determine its cytotoxic effects (Table 3). The ethyl acetate leaf extract of A. muricata was assayed against three Leishmania species (PH8, M2903 and PP75) and Trypanosoma cruzi. Promising activity was reported with $\mathrm{IC}_{50}$ values lower than $25 \mu \mathrm{g} / \mathrm{mL}$ [112]. The same promising antileishmanial effect was reported against $L$. braziliensis and $L$. panamensis species with a toxicity effect higher than Glucantime, which was used as a positive control [26]. A bioassay-guided investigation on the A. muricata seeds against three Leishmania species, namely donovani, mexicana and major, led to the isolation of two AGEs as the bioactive compounds. Isolated annonacinone and corossolone elicited an $\mathrm{EC}_{50}$ dose of $6.72-8.00$ and $16.14-18.73 \mu \mathrm{g} / \mathrm{mL}$ against the tested species, respectively [53]. A bioassay-guided investigation on the seeds of A. muricata against two forms of L. chagasi, promastigote and amastigote, also led to the isolation of the same bioactive AGE compounds, annonacinone and corossolone [54]. In addition, the methanolic extract of A. muricata seeds showed significant antiparasitic activity against the infective larvae of Molinema dessetae, and this activity was contributed to its isolated AGEs [113]. A recent in vitro investigation on A. muricata aqueous leaf extract was performed against Haemonchus contortus, a gastrointestinal parasite. The result showed $89.08 \%$ and $84.91 \%$ toxicity against larvae and eggs as assessed by larval motility and egg hatch tests. The immobilization of adult worms within 6 to $8 \mathrm{~h}$ of exposure to different doses of the extract revealed a promising anthelmintic activity in the leaves [114]. 
Table 3. Antiparasitic studies on A. muricata.

\begin{tabular}{|c|c|c|c|}
\hline Plant Part & Subject of Study & Result & Reference \\
\hline $\begin{array}{l}\text { ethyl acetate extract } \\
\text { of the leaves }\end{array}$ & $\begin{array}{l}\text { Leishmania species (PH8, } \\
\text { M2903, PP75), T. cruzi }\end{array}$ & $\mathrm{IC}_{50}$ values lower than $25 \mu \mathrm{g} / \mathrm{mL}$ & {$[112]$} \\
\hline $\begin{array}{l}\text { ethyl acetate extract } \\
\text { of the pericarp }\end{array}$ & $\begin{array}{l}\text { L. braziliensis, } \\
\text { L. panamensis }\end{array}$ & $\begin{array}{l}\text { toxicity effect higher than Glucantime as } \\
\text { a positive control }\end{array}$ & {$[26]$} \\
\hline $\begin{array}{l}\text { methanol extract of } \\
\text { the seeds }\end{array}$ & $\begin{array}{l}\text { L. donovani, L. mexicana, } \\
\text { L. major }\end{array}$ & $\begin{array}{c}\text { bioassay-guided isolation of annonacinone } \\
\left(\mathrm{EC}_{50}: 6.72-8.00 \mu \mathrm{g} / \mathrm{mL}\right) \text { and corossolone } \\
\left(\mathrm{EC}_{50}: 16.14-18.73 \mu \mathrm{g} / \mathrm{mL}\right)\end{array}$ & {$[53]$} \\
\hline $\begin{array}{l}\text { methanol-water } \\
\text { extract of the seeds }\end{array}$ & $\begin{array}{l}\text { L. chagasi (promastigote } \\
\text { amastigote) }\end{array}$ & $\begin{array}{l}\text { bioassay-guided isolation of } \\
\text { annonacinone and corossolone }\end{array}$ & {$[54]$} \\
\hline $\begin{array}{c}\text { aqueous extract of } \\
\text { the leaves }\end{array}$ & H. contortus & $\begin{array}{c}\text { toxicity against larvae }(89.08 \%) \\
\text { and egg }(84.91 \%)\end{array}$ & {$[114]$} \\
\hline $\begin{array}{l}\text { pentane extract of } \\
\text { the leaves }\end{array}$ & P. falciparum & $\begin{array}{l}\text { toxicity against chloroquine } \\
\text { sensitive and }\left(\mathrm{IC}_{50}: 16 \mu \mathrm{g} / \mathrm{mL}\right) \text { and } \\
\text { resistant strains }\left(\mathrm{IC}_{50}: 8 \mu \mathrm{g} / \mathrm{mL}\right)\end{array}$ & {$[115]$} \\
\hline
\end{tabular}

Antiplasmodial Activity

Malaria, one of the most debilitating diseases, afflicts a substantial population in tropical and subtropical zones [116]. The available antimalarial drugs demonstrate varying degrees of failure due to rapid spread of parasite resistance [117]. Therefore, research into new antiplasmodial agents against the pathogenic parasites is definitely warranted. The pentane leaf extract of $A$. muricata was assayed against two strains of Plasmodium falciparum: the Nigerian chloroquine-sensitive strain and FcM29-Cameroon (chloroquine-resistant strain); a promising antiplasmodial effect was obtained with an IC50 value of 16 and $8 \mu \mathrm{g} / \mathrm{mL}$ after $72 \mathrm{~h}$, respectively [115]. The leaf extract, also at $20 \mu \mathrm{g} / \mathrm{mL}$, showed a $67 \%$ inhibition against an asynchronous F32 strain of P. falciparum [118]. Another study on different extracts of A. muricata leaves and stems also confirmed the reported cytotoxic effects against the chloroquine-sensitive (F32) and -resistant (W2) P. falciparum [112]. These findings substantiated the traditional use of A. muricata as an antimalarial agent.

\subsection{Hepatoprotective and Bilirubin-Lowering Activity}

A. muricata is traditionally employed to treat jaundice in Ghana. A study was conducted to determine the in vivo bilirubin-lowering potential of the aqueous extract of $A$. muricata leaves. This study was performed on phenylhydrazine-induced jaundice in adult rats, and the levels of direct and total bilirubin were measured in rats orally treated with 50 and $400 \mathrm{mg} / \mathrm{kg}$ of the extract. The extract at both doses caused a significant reduction to hyperbilirubinemia, which was close to normal levels [119]. In addition, the hepatoprotective effect was also reported for the aqueous extract of the leaves against carbon tetrachloride and acetaminophen-induced liver damage. Pretreatment with different concentrations of the extract $(50,100,200$, and $400 \mathrm{mg} / \mathrm{kg}$ ) for 7 days prior to liver damage restored liver function toward normal hemostasis, which was shown by biochemical and histological analyses [120]. Therefore, these findings substantiated the traditional use of A. muricata against jaundice and showed the potential hepatoprotective activity. 


\subsection{Insecticidal Activity}

Botanical insecticides can have a pivotal role in different agriculture programs, especially in small farming [121]. Due to the presence of AGEs, plants from the Annonaceae family such as A. mucosa and A. sylvatica have shown to be promising biopesticides among tropical plants [72,122]. An investigation on different Annona species showed the growth inhibition effect of A. muricata seeds and contact toxicity by topical administration to Trichoplusia ni larvae [122]. In another study, different extracts of A. muricata seeds were examined against Sitophilus zeamais, a detrimental pest for stored grains, using ingestion and topical assays. Promising activity was obtained from the ingestion application of hexane and ethyl acetate extracts, and this activity was contributed to the presence of AGEs in the less polar fractions [123]. By dipping and surface-protectant methods, the seed extracts revealed weevil mortality of $70 \%$ and $100 \%$ against $S$. zeamais at $20 \%(v / v)$ and $0.4 \%(v / w)$ concentrations, respectively [124].

Mosquito-controlling activity of both the aqueous and oil extracts of $A$. muricata seeds against the larvae and adults of Aedes albopictus and Culex quinquefasciatus demonstrated promising bioactivity with lethal concentration 50 ( $\mathrm{LC}_{50}$ ) values ranging from $0.5 \%$ to $1 \%$ for larvae and $1 \%$ to $5 \%$ for adults [125]. In another study, this activity for the ethanolic extract of the leaves against $C$. quinquefasciatus was also reported with an $\mathrm{LC}_{50}$ value of $20.87 \mu \mathrm{g} / \mathrm{mL}$ after $24 \mathrm{~h}$ [126]. In addition, the larvae of the Aedes aegypti mosquito, the transmitters of dengue fever, elicited high susceptibility to the ethanolic extract of the seeds with the $\mathrm{LC}_{50}$ of $224.27 \mathrm{ppm}$ [127]. A. muricata seeds showed more than five times synergistic larvicidal activity when combined with Piper nigrum fruit ethanolic extracts (A. muricata 90:10 P. nigrum) [128]. The fractionation analysis of the extract showed that $n$-hexane is the most active fraction with an $\mathrm{LC}_{50}$ of $73.77 \mathrm{ppm}$. The leaf extract of $A$. muricata also showed a time-dependent toxicity against the larvae of Anastrepha ludens (Mexican fruit fly) with a mortality rate of $63 \%$ to 74\% [129]. Leatemia et al. [130] investigated the growth inhibition potential of the ethanolic seed extracts of A. muricata isolated from different locations against polyphagous lepidopteran Spodoptera litura. The surprising result showed significant differences for the growth inhibition based on the isolated locations ranging from $18 \%$ to $96 \%$ compared with the control (ethanol) [130]. The ethanolic leaf extract $(1.0 \mathrm{~g} / \mathrm{L})$ showed $40 \%, 80 \%$ and $98 \%$ mortality against Callosobruchus maculatus (Fabricius) after 24, 48 and $72 \mathrm{~h}$ post-treatment, respectively. At the same concentration, the extract significantly decreased the oviposition of $C$. maculatus and appeared to be a promising protectant against the respective insect in stored cowpea [131]. This growing body of experimental evidence supports the idea that $A$. muricata exhibits insecticidal activity against assorted types of insects.

\subsection{Gastroprotective Activity}

Gastroprotective activity of $A$. muricata leaves was examined against ethanol-induced gastric injury. The results of the oral administration of the ethyl acetate extract (200 and $400 \mathrm{mg} / \mathrm{kg}$ ) showed significant antiulcer potential, which was mediated through protective effects against gastric wall mucosal damages [100]. Immunohistochemical staining demonstrated that the leaf extract decreased the Bax protein expression and elevated the Hsp70 protein expression. The effect of the extract on the gastric tissues was accompanied with augmentation in the activity of enzymatic antioxidants and suppression 
of lipid peroxidation, representing the preservative effect against gastric wall mucus [132]. These findings strongly suggested the gastroprotective potential of the A. muricata leaves.

\subsection{Molluscicidal Activity}

To establish plant-derived molluscicides for the vector control of schistosomiasis, different parts of the Annona species were tested against Biomphalaria glabrata, both in egg masses and adult forms. Santos and colleagues, in 2001, demonstrated that the leaves of $A$. muricata possess significant toxicity against adult worms with an $\mathrm{LD}_{90}$ value of $8.75 \mathrm{ppm}$. Additional toxicity of the A. muricata leaves against snail egg masses was markedly noted among different Annona species [133]. A bioassay-guided investigation on the cytotoxicity of the ethanolic extract of $A$. muricata leaves against the larvae of the brine shrimp Artemia salina and the snail B. glabrata showed the potent molluscicidal activity of this plant. This study led to the isolation of three bioactive compounds of annonacin, goniothalamicin and isoannonacin [49].

\subsection{Wound Healing Activity}

Moghadamtousi and colleagues [134] investigated the wound healing activity of the ethyl acetate extract of $A$. muricata leaves (5\% w/w and $10 \% \mathrm{w} / \mathrm{w})$ against excisional wound healing in rats. Topical administration of the extract for 15 days demonstrated significant wound healing potential assessed by macroscopic and microscopic analyses. The anti-inflammatory effects of the extract were demonstrated during the healing process as shown by the up-regulation of Hsp70, as assessed by immunohistochemical evaluation. The antioxidant defense also fortified the wound healing activity of $A$. muricata leaves. The same experiment using the alcoholic extract of the stem bark also showed a significant reduction in the wound area from the 4 th day after injury onwards [135]. These studies showed that AGEs from A. muricata may have potential wound healing activity against excisional wounds.

\section{Toxicology}

In 1999, a study published in the Lancet Journal discussed the possible relationship between the consumption of tropical fruits and the incidence of atypical Parkinsonism in the French West Indies [136]. In addition, the etiology of a neurodegenerative disease in Guadeloupe Island revealed a close correlation between AGE consumption and the endemic of this disease [50]. Hence, AGEs are suggested to be environmental neurotoxins responsible for neurodegenerative disorders, including Guadeloupean atypical Parkinsonism. A recent study showed that the fruit of $A$. muricata with annonacin as a major AGE may be a potential risk factor for neurodegeneration due to being a major source of exposure to AGEs [137]. In rat striatal neurons, annonacin depleted the ATP supply and interrupted the transportation of mitochondria to the cell soma, which caused cellular perturbations in the protein tau and led to a number of similar characteristics as neurodegenerative diseases [50]. It is projected that if someone consumes one soursop fruit or its nectar daily, after one year, the total amount of annonacin which was ingested is sufficient to induce brain lesions in rats through intravenous infusion [138]. Hence, excessive consumption of products from Annonaceae species should be precisely considered to prevent any neurotoxic damages. 


\section{Conclusions}

A. muricata is a coveted tropical tree, and a wealth of phytochemical investigations have been conducted for this fruit plant. In addition to being an important source for the food industry and an indigenous medicinal plant, A. muricata is proven to possess a wide spectrum of biological activities. Among all former studies on this plant, the most promising activities are found to be its anticancer, antiparasitic and insecticidal activity. Because the majority of the previous studies were focused on the biological activities of the plant extract, further investigations on the biochemical and physiological functions of active compounds and the detailed mechanisms underlying these activities are completely pivotal for the development of pharmaceutical and agricultural products. In addition, clinical trials concerning the rich pharmaceutical potential of $A$. muricata have been markedly neglected in previous studies. Several reports on the neurodegenerative effects of $A$. muricata and its isolated AGEs are completely perplexing, and further research is crucial to distinguish all the compounds contributing to this effect and determine the threshold of these compounds at which this effect is caused. This review is hoped to be a source of enlightenment and motivation for researchers to further perform in vitro, in vivo and clinical investigations on the biological activities of $A$. muricata to gain insight into developing new agricultural and pharmaceutical agents.

\section{Acknowledgments}

This research was supported by the University of Malaya High Impact Research (UM-MOHE UM.C/625/1/HIR/MOHE/SC/09), the University of Malaya Research Grant (RP001-2012C), FP040-2014A and the Postgraduate Research Fund (PG118-2013A).

\section{Conflicts of Interest}

The authors declare no conflict of interest.

\section{References}

1. Moghadamtousi, S.Z.; Goh, B.H.; Chan, C.K.; Shabab, T.; Kadir, H.A. Biological activities and phytochemicals of Swietenia macrophylla king. Molecules 2013, 18, 10465-10483.

2. Moghadamtousi, S.Z.; Kamarudin, M.N.A.; Chan, C.K.; Goh, B.H.; Kadir, H.A. Phytochemistry and biology of Loranthus parasiticus merr, a commonly used herbal medicine. Am. J. Chin. Med. 2014, 42, 23-35.

3. Mishra, S.; Ahmad, S.; Kumar, N.; Sharma, B.K. Annona muricata (the cancer killer): A review. Glob. J. Pharm. Res. 2013, 2, 1613-1618.

4. Leboeuf, M.; Cavé, A.; Bhaumik, P.; Mukherjee, B.; Mukherjee, R. The phytochemistry of the annonaceae. Phytochemistry 1980, 21, 2783-2813.

5. Adewole, S.O.; Caxton-Martins, E.A. Morphological changes and hypoglycemic effects of Annona muricata Linn. (Annonaceae) leaf aqueous extract on pancreatic B-cells of streptozotocin-treated diabetic rats. Afr. J. Biomed. Res. 2006, 9, 173-187. 
6. De Souza, R.; Benassi, E.; da Silva, R.R.; Afonso, S.; Scarminio, I.S. Enhanced extraction yields and mobile phase separations by solvent mixtures for the analysis of metabolites in Annona muricata L. Leaves. J. Sep. Sci. 2009, 32, 4176-4185.

7. De Sousa, O.V.; Vieira, G.D.-V.; de Pinho, J.D.J.R.; Yamamoto, C.H.; Alves, M.S. Antinociceptive and anti-inflammatory activities of the ethanol extract of Annona muricata L. leaves in animal models. Int. J. Mol. Sci. 2010, 11, 2067-2078.

8. Adewole, S.; Ojewole, J. Protective effects of Annona muricata linn.(annonaceae) leaf aqueous extract on serum lipid profiles and oxidative stress in hepatocytes of streptozotocin-treated diabetic rats. Afr. J. Tradit. Complement. Altern. Med. 2009, 6, 30-41.

9. Watt, J.M.; Breyer-Bnodwijk, M. The Medicinal and Poisonous Plants of Southern and Eastern Africa: Being an Account of Their Medicinal and Other Uses, Chemical Composition, Pharmacological Effects Aod Toricotogy in Man and Annimal; Lívingstone Ltd.: Edinburgh, UK; London, UK, 1962.

10. Ong, H.; Norzalina, J. Malay herbal medicine in Gemencheh, Negri Sembilan, Malaysia. Fitoterapia 1999, 70, 10-14.

11. Jaramillo-Flores, M.; Hernandez-Sanchez, H. Thermal diffusivity of soursop (Annona muricata L.) pulp. J. Food Eng. 2000, 46, 139-143.

12. Wu, F.-E.; Gu, Z.-M.; Zeng, L.; Zhao, G.-X.; Zhang, Y.; McLaughlin, J.L.; Sastrodihardjo, S. Two new cytotoxic monotetrahydrofuran annonaceous acetogenins, annomuricins a and $\mathrm{b}$, from the leaves of Annona muricata. J. Nat. Prod. 1995, 58, 830-836.

13. Yang, C.; Gundala, S.R.; Mukkavilli, R.; Vangala, S.; Reid, M.D.; Aneja, R., Synergistic interactions among flavonoids and acetogenins in graviola (Annona muricata) leaves confer protection against prostate cancer. Carcinogenesis 2015, 2015, doi:10.1093/carcin/bgv1046.

14. Matsushige, A.; Matsunami, K.; Kotake, Y.; Otsuka, H.; Ohta, S. Three new megastigmanes from the leaves of Annona muricata. J. Nat. Med. 2012, 66, 284-291.

15. Nawwar, M.; Ayoub, N.; Hussein, S.; Hashim, A.; El-Sharawy, R.; Wende, K.; Harms, M.; Lindequist, U. Flavonol triglycoside and investigation of the antioxidant and cell stimulating activities of Annona muricata linn. Arch. Pharm. Res. 2012, 35, 761-767.

16. Jiménez, V.M.; Gruschwitz, M.; Schweiggert, R.M.; Carle, R.; Esquivel, P. Identification of phenolic compounds in soursop (Annona muricata) pulp by high-performance liquid chromatography with diode array and electrospray ionization mass spectrometric detection. Food Res. Int. 2014, 65, 42-46.

17. Pélissier, Y.; Marion, C.; Kone, D.; Lamaty, G.; Menut, C.; Bessière, J.-M. Volatile components of Annona muricata L. J. Essent. Oil Res. 1994, 6, 411-414.

18. Kossouoh, C.; Moudachirou, M.; Adjakidje, V.; Chalchat, J.-C.; Figuérédo, G. Essential oil chemical composition of Annona muricata L. Leaves from benin. J. Essent. Oil Res. 2007, 19, 307-309.

19. Rupprecht, J.K.; Hui, Y.-H.; McLaughlin, J.L. Annonaceous acetogenins: A review. J. Nat. Prod. 1990, 53, 237-278. 
20. Gyamfi, K.; Sarfo, D.; Nyarko, B.; Akaho, E.; Serfor-Armah, Y.; Ampomah-Amoako, E. Assessment of elemental content in the fruit of graviola plant, Annona muricata, from some selected communities in ghana by instrumental neutron activation analysis. Elixir Food Sci. 2011, $41,5671-5675$.

21. Hasrat, J.; Bruyne, T.D.; Backer, J.P.; Vauquelin, G.; Vlietinck, A. Isoquinoline derivatives isolated from the fruit of Annona muricata as 5-HTergic 5-HT1A receptor agonists in rats: Unexploited antidepressive (lead) products. J. Pharm. Pharmacol. 1997, 49, 1145-1149.

22. Hasrat, J.; Pieters, L.; de Backer, J.-P.; Vauquelin, G.; Vlietinck, A. Screening of medicinal plants from suriname for 5- $\mathrm{HT}_{1 \mathrm{~A}}$ ligands: Bioactive isoquinoline alkaloids from the fruit of Annona muricata. Phytomedicine 1997, 4, 133-140.

23. Melot, A.; Fall, D.; Gleye, C.; Champy, P. Apolar annonaceous acetogenins from the fruit pulp of Annona muricata. Molecules 2009, 14, 4387-4395.

24. Ragasa, C.Y.; Soriano, G.; Torres, O.B.; Don, M.-J.; Shen, C.-C. Acetogenins from Annona muricata. Pharmacog. J. 2012, 4, 32-37.

25. Sun, S.; Liu, J.; Kadouh, H.; Sun, X.; Zhou, K. Three new anti-proliferative annonaceous acetogenins with mono-tetrahydrofuran ring from graviola fruit (Annona muricata). Bioorg. Med. Chem. Lett. 2014, 24, 2773-2776.

26. Jaramillo, M.; Arango, G.; Gonzalez, M.; Robledo, S.; Velez, I.D. Cytotoxicity and antileishmanial activity of Annona muricata pericarp. Fitoterapia 2000, 71, 183-186.

27. Wu, F.-E.; Zeng, L.; Gu, Z.-M.; Zhao, G.-X.; Zhang, Y.; Schwedler, J.T.; McLaughlin, J.L.; Sastrodihardjo, S. New bioactive monotetrahydrofuran annonaceous acetogenins, annomuricin c and muricatocin c, from the leaves of Annona muricata. J. Nat. Prod. 1995, 58, 909-915.

28. Kim, G.-S.; Zeng, L.; Alali, F.; Rogers, L.L.; Wu, F.-E.; McLaughlin, J.L.; Sastrodihardjo, S. Two new mono-tetrahydrofuran ring acetogenins, annomuricin e and muricapentocin, from the leaves of Annona muricata. J. Nat. Prod. 1998, 61, 432-436.

29. Wu, F.-E.; Zhao, G.-X.; Zeng, L.; Zhang, Y.; Schwedler, J.T.; McLaughlin, J.L.; Sastrodihardjo, S. Additional Bioactive Acetogenins, Annomutacin and (2, 4-trans and cis)-10R-Annonacin-A-ones, from the Leaves of Annona muricata. J. Nat. Prod. 1995, 58, 1430-1437.

30. Zeng, L.; Wu, F.-E.; McLaughlin, J.L. Annohexocin, a novel mono-THF acetogenin with six hydroxyls, from Annona muricata (annonaceae). Bioorg. Med. Chem. Lett. 1995, 5, 1865-1868.

31. Wu, F.-E.; Zeng, L.; Gu, Z.-M.; Zhao, G.-X.; Zhang, Y.; Schwedler, J.T.; McLaughlin, J.L.; Sastrodihardjo, S. Muricatocins a and b, two new bioactive monotetrahydrofuran annonaceous acetogenins from the leaves of Annona muricata. J. Nat. Prod. 1995, 58, 902-908.

32. Li, D.-Y.; Yu, J.-G.; Zhu, J.-X.; Yu, D.-L.; Luo, X.-Z.; Sun, L.; Yang, S.-L. Annonaceous acetogenins of the seeds from Annona muricata. J. Asian Nat. Prod. Res. 2001, 3, 267-276.

33. Yu, J.-G.; Gui, H.-Q.; Luo, X.-Z.; Sun, L. Murihexol, a linear acetogenin from Annona muricata. Phytochemistry 1998, 49, 1689-1692.

34. Zeng, L.; Wu, F.-E.; Oberlies, N.H.; McLaughlin, J.L.; Sastrodihadjo, S. Five new monotetrahydrofuran ring acetogenins from the leaves of Annona muricata. J. Nat. Prod. 1996, 59, 1035-1042. 
35. Zeng, L.; Wu, F.-E.; Gu, Z.-M.; McLaughlin, J.L. Murihexocins A and B, two novel mono-THF acetogenins with six hydroxyls, from Annona muricata (Annonaceae). Tetrahedron Lett. 1995, 36, 5291-5294.

36. Kim, G.-S.; Zeng, L.; Alali, F.; Rogers, L.L.; Wu, F.-E.; Sastrodihardjo, S.; McLaughlin, J.L. Muricoreacin and murihexocin C, mono-tetrahydrofuran acetogenins, from the leaves of Annona muricata in honour of professor gh neil towers 75th birthday. Phytochemistry 1998, 49, 565-571.

37. Liaw, C.-C.; Chang, F.-R.; Lin, C.-Y.; Chou, C.-J.; Chiu, H.-F.; Wu, M.-J.; Wu, Y.-C. New cytotoxic monotetrahydrofuran annonaceous acetogenins from Annona muricata. J. Nat. Prod. 2002, 65, 470-475.

38. Chang, F.-R.; Liaw, C.-C.; Lin, C.-Y.; Chou, C.-J.; Chiu, H.-F.; Wu, Y.-C. New adjacent bis-tetrahydrofuran annonaceous acetogenins from Annona muricata. Planta Med. 2003, 69, 241-246.

39. Fofana, S.; Ziyaev, R.; Abdusamatov, A.; Zakirov, S.K. Alkaloids from Annona muricata leaves. Chem. Nat. Compd. 2011, 47, 321-321.

40. Matsushige, A.; Kotake, Y.; Matsunami, K.; Otsuka, H.; Ohta, S.; Takeda, Y. Annonamine, a new aporphine alkaloid from the leaves of Annona muricata. Chem. Pharm. Bull. 2012, 60, 257-259.

41. Gleye, C.; Laurens, A.; Hocquemiller, R.; Cavé, A.; Laprévote, O.; Serani, L. Isolation of montecristin, a key metabolite in biogenesis of acetogenins from Annona muricata and its structure elucidation by using tandem mass spectrometry. J. Org. Chem. 1997, 62, 510-513.

42. Gleye, C.; Laurens, A.; Hocquemiller, R.; Laprévote, O.; Serani, L.; Cavé, A. Cohibins a and b, acetogenins from roots of Annona muricata. Phytochemistry 1997, 44, 1541-1545.

43. Gleye, C.; Duret, P.; Laurens, A.; Hocquemiller, R.; Cavé, A. cis-monotetrahydrofuran acetogenins from the roots of Annona muricata L. J. Nat. Prod. 1998, 61, 576-579.

44. Gleye, C.; Raynaud, S.; Hocquemiller, R.; Laurens, A.; Fourneau, C.; Serani, L.; Laprévote, O.; Roblot, F.; Leboeuf, M.; Fournet, A. Muricadienin, muridienins and chatenaytrienins, the early precursors of annonaceous acetogenins. Phytochemistry 1998, 47, 749-754.

45. Gleye, C.; Akendengue, B.; Laurens, A.; Hocquemiller, R. Coronin from roots of annona muricata, a putative intermediate in acetogenin biosynthesis (1). Planta Med. 2001, 67, 570-572.

46. Gleye, C.; Laurens, A.; Laprévote, O.; Serani, L.; Hocquemiller, R. Isolation and structure elucidation of sabadelin, an acetogenin from roots of Annona muricata. Phytochemistry 1999, 52, 1403-1408.

47. Myint, S.H.; Laurens, A.; Hocquemiller, R.; Cavé, A.; Davoust, D.; Cortes, D. Murisolin: A new cytotoxic mono-tetrahydrofuran- $\gamma$-lactone from Annona muricata. Heterocycles 1990, 31, 861-867.

48. Rieser, M.J.; Kozlowski, J.F.; Wood, K.V.; McLaughlin, J.L. Muricatacin: A simple biologically active acetogenin derivative from the seeds of Annona muricata (annonaceae). Tetrahedron Lett. 1991, 32, 1137-1140.

49. Luna, J.D.S.; de Carvalho, J.; de Lima, M.; Bieber, L.; Bento, E.D.S.; Franck, X.; Sant'Ana, A. Acetogenins in Annona muricata L. (annonaceae) leaves are potent molluscicides. Nat. Prod. Res. 2006, 20, 253-257.

50. Escobar-Khondiker, M.; Höllerhage, M.; Muriel, M.-P.; Champy, P.; Bach, A.; Depienne, C.; Respondek, G.; Yamada, E.S.; Lannuzel, A.; Yagi, T. Annonacin, a natural mitochondrial complex I inhibitor, causes tau pathology in cultured neurons. J. Neurosci. 2007, 27, 7827-7837. 
51. Champy, P.; Höglinger, G.U.; Féger, J.; Gleye, C.; Hocquemiller, R.; Laurens, A.; Guérineau, V.; Laprévote, O.; Medja, F.; Lombès, A. Annonacin, a lipophilic inhibitor of mitochondrial complex I, induces nigral and striatal neurodegeneration in rats: Possible relevance for atypical parkinsonism in guadeloupe. J. Neurochem. 2004, 88, 63-69.

52. Cortes, D.; Myint, S.H.; Laurens, A.; Hocquemiller, R.; Leboeuf, M.; Cavé, A. Corossolone et corossoline, deux nouvelles $\gamma$-lactones mono-tétrahydrofuraniques cytotoxiques. Can. J. Chem. 1991, 69, 8-11.

53. Vila-Nova, N.S.; de Morais, S.M.; Falcão, M.J.C.; Alcantara, T.T.N.; Ferreira, P.A.T.; Cavalcanti, E.S.B.; Vieira, I.G.P.; Campello, C.C.; Wilson, M. Different susceptibilities of Leishmania spp. promastigotes to the Annona muricata acetogenins annonacinone and corossolone, and the Platymiscium floribundum coumarin scoparone. Exp. Parasitol. 2013, 133, 334-338.

54. Vila-Nova, N.S.; Morais, S.M.D.; Falcão, M.J.C.; Machado, L.K.A.; Beviláqua, C.M.L.; Costa, I.R.S.; Brasil, N.V.G.P.D.; Andrade Júnior, H.F.D. Leishmanicidal activity and cytotoxicity of compounds from two Annonacea species cultivated in northeastern Brazil. Rev. Soc. Bras. Med. Trop. 2011, 44, 567-571.

55. Hla Myint, S.; Cortes, D.; Laurens, A.; Hocquemiller, R.; Lebęuf, M.; Cavé, A.; Cotte, J.; Quéro, A.-M. Solamin, a cytotoxic mono-tetrahydrofuranic $\gamma$-lactone acetogenin from Annona muricata seeds. Phytochemistry 1991, 30, 3335-3338.

56. Gromek, D.; Figadère, B.; Hocquemiller, R.; Cavé, A.; Cortes, D. Corepoxylone, a possible precursor of mono-tetrahydrofuran $\gamma$-lactone acetogenins: Biomimetic synthesis of corossolone. Tetrahedron 1993, 49, 5247-5252.

57. Rieser, M.J.; Fang, X.-P.; Rupprecht, J.K.; Hui, Y.-H.; Smith, D.L.; McLaughlin, J.L. Bioactive single-ring acetogenins from seed extracts of Annona muricata. Planta Med. 1993, 59, 91-92.

58. Rieser, M.J.; Fang, X.P.; Anderson, J.E.; Miesbauer, L.R.; Smith, D.L.; McLaughlin, J.L. Muricatetrocins $\mathrm{a}$ and $\mathrm{b}$ and gigantetrocin $\mathrm{b}$ : Three new cytotoxic monotetrahydrofuran-ring acetogenins from Annona muricata. Helv. Chim. Acta 1993, 76, 2433-2444.

59. Roblot, F.; Laugel, T.; Lebœuf, M.; Cavé, A.; Laprévote, O. Two acetogenins from Annona muricata seeds. Phytochemistry 1993, 34, 281-285.

60. Li, C.-M.; Tan, N.-H.; Lu, Y.-P.; Liang, H.-L.; Mu, Q.; Zheng, H.; Hao, X.; Wu, Y.; Zhou, J. Annomuricatin A, a new cyclopeptide from the seeds of Annona muricata. Acta Bot. Yunnanica 1995, 17, 459-462.

61. Li, C.M.; Tan, N.H.; Zheng, H.L.; Mu, Q.; Hao, X.J.; He, Y.N.; Zou, J. Cyclopeptide from the seeds of Annona muricata. Phytochemistry 1998, 48, 555-556.

62. Wélé, A.; Zhang, Y.; Caux, C.; Brouard, J.-P.; Pousset, J.-L.; Bodo, B. Annomuricatin C, a novel cyclohexapeptide from the seeds of Annona muricata. Comptes Rendus Chim. 2004, 7, 981-988.

63. Rieser, M.J.; Gu, Z.-M.; Fang, X.-P.; Zeng, L.; Wood, K.V.; McLaughlin, J.L. Five novel mono-tetrahydrofuran ring acetogenins from the seeds of Annona muricata. J. Nat. Prod. 1996, 59, 100-108.

64. Gleye, C.; Raynaud, S.; Fourneau, C.; Laurens, A.; Laprévote, O.; Serani, L.; Fournet, A.; Hocquemiller, R. Cohibins $\mathrm{C}$ and $\mathrm{D}$, two important metabolites in the biogenesis of acetogenins from Annona muricata and Annona nutans. J. Nat. Prod. 2000, 63, 1192-1196. 
65. De Yu, L.; Yu, J.G.; Luo, X.Z.; Lan, S.; Yang, S.L. Muricatenol, a linear acetogenin from annona muricata (Annonaceae). Chin. Chem. Lett. 2000, 11, 239-242.

66. Chang, F.-R.; Wu, Y.-C. Novel cytotoxic annonaceous acetogenins from Annona muricata. J. Nat. Prod. 2001, 64, 925-931.

67. Hisham, A.; Sreekala, U.; Pieters, L.; Bruyne, T.D.; van den Heuvel, H.; Claeys, M. Epoxymurins $\mathrm{a}$ and $\mathrm{b}$, two biogenetic precursors of annonaceous acetogenins from Annona muricata. Tetrahedron 1993, 49, 6913-6920.

68. Leboeuf, M.; Legueut, C.; Cavé, A.; Desconclois, J.; Forgacs, P.; Jacquemin, H. Alcaloïdes des annonacées XXIX1: Alcaloïdes de l'Annona muricata L. (in French). Planta Med. 1981, 42, 37-44.

69. Fekam Boyom, F.; Amvam Zollo, P.; Menut, C.; Lamaty, G.; Bessière, J. Aromatic plants of tropical central africa. Part XXVII. Comparative study of the volatile constituents of five annonaceae species growing in cameroon. Flavour Frag. J. 1996, 11, 333-338.

70. Thang, T.; Dai, D.; Hoi, T.; Ogunwande, I. Study on the volatile oil contents of Annona glabra L., Annona squamosa L., Annona muricata L. and Annona reticulata L., from Vietnam. Nat. Prod. Res. 2013, 27, 1232-1236.

71. Jirovetz, L.; Buchbauer, G.; Ngassoum, M.B. Essential oil compounds of the Annona muricata fresh fruit pulp from cameroon. J. Agric. Food Chem. 1998, 46, 3719-3720.

72. Alali, F.Q.; Liu, X.-X.; McLaughlin, J.L. Annonaceous acetogenins: Recent progress. J. Nat. Prod. 1999, 62, 504-540.

73. Tempesta, M.S.; Kriek, G.R.; Bates, R.B. Uvaricin, a new antitumor agent from Uvaria accuminata (annonaceae). J. Org. Chem. 1982, 47, 3151-3153.

74. McLaughlin, J.L. Paw paw and cancer: Annonaceous acetogenins from discovery to commercial products. J. Nat. Prod. 2008, 71, 1311-1321.

75. Carmen Zafra-Polo, M.; Figadère, B.; Gallardo, T.; Tormo, J.; Cortes, D. Natural acetogenins from annonaceae, synthesis and mechanisms of action. Phytochemistry 1998, 48, 1087-1117.

76. Zafra-Polo, M.C.; González, M.C.; Estornell, E.; Sahpaz, S.; Cortes, D. Acetogenins from annonaceae, inhibitors of mitochondrial complex I. Phytochemistry 1996, 42, 253-271.

77. Chih, H.-W.; Chiu, H.-F.; Tang, K.-S.; Chang, F.-R.; Wu, Y.-C. Bullatacin, a potent antitumor annonaceous acetogenin, inhibits proliferation of human hepatocarcinoma cell line 2.2.15 by apoptosis induction. Life Sci. 2001, 69, 1321-1331.

78. Chan, P.; Ah, R.; Mh, K. Anti-arthritic activities of Annona muricata L. Leaves extract on complete freund's adjuvant (CFA)-induced arthritis in rats. Planta Med. 2010, 76, P166, doi:10.1055/s-0030-1264464.

79. Arroyo, J.; Prashad, M.; Vásquez, Y.; Li, E.; Tomás, G. Actividad citotóxica in vitro de la mezcla de Annona muricata y krameria lappacea sobre células cancerosas de glándula mamaria, pulmón y sistema nervioso central (in Spanish). Rev. Perú. Med. Exp. Salud Publica 2005, 22, 247-253.

80. Astirin, O.P.; Artanti, A.N.; Fitria, M.S.; Perwitasari, E.A.; Prayitno, A. Annonaa muricata linn leaf induce apoptosis in cancer cause virus. J. Cancer Ther. 2013, 4, 1244-1250.

81. Gavamukulya, Y.; Abou-Elella, F.; Wamunyokoli, F.; AEl-Shemy, H. Phytochemical screening, anti-oxidant activity and in vitro anticancer potential of ethanolic and water leaves extracts of Annona muricata (graviola). Asian Pac. J. Trop. Med. 2014, 7, S355-S363. 
82. George, V.C.; Kumar, D.; Rajkumar, V.; Suresh, P.; Kumar, R.A. Quantitative assessment of the relative antineoplastic potential of the $n$-butanolic leaf extract of Annona muricata linn. In normal and immortalized human cell lines. Asian Pac. J. Cancer Prev. 2012, 13, 699-704.

83. Moghadamtousi, S.Z.; Kadir, H.A.; Paydar, M.; Rouhollahi, E.; Karimian, H. Annona muricata leaves induced apoptosis in A549 cells through mitochondrial-mediated pathway and involvement of NF-кB. BMC Complement. Altern. Med. 2014, 14, 299.

84. Moghadamtousi, S.Z.; Karimian, H.; Rouhollahi, E.; Paydar, M.; Fadaeinasab, M.; Kadir, H.A. Annona muricata leaves induce $\mathrm{g}_{1}$ cell cycle arrest and apoptosis through mitochondria-mediated pathway in human HCT-116 and HT-29 colon cancer cells. J. Ethnopharmacol. 2014, 156, 277-289.

85. Ezirim, A.; Okachi, V.; James, A.; Adebeshi, O.; Ogunnowo, S.; Odeghe, O. Induction of apoptosis in myelogenous leukemic k562 cells by ethanolic leaf extract of Annona muricata. Indian J. Drug Dis. 2013, 2, 142-151.

86. Asare, G.A.; Afriyie, D.; Ngala, R.A.; Abutiate, H.; Doku, D.; Mahmood, S.A.; Rahman, H. Antiproliferative activity of aqueous leaf extract of Annona muricata L. On the prostate, BPH-1 cells, and some target genes. Integr. Cancer Ther. 2015, 14, 65-74.

87. Minari, J.; Okeke, U. Chemopreventive effect of Annona muricata on DMBA-induced cell proliferation in the breast tissues of female albino mice. Egypt. J. Med. Hum. Genet. 2014, 15, 327-334.

88. Hamizah, S.; Roslida, A.; Fezah, O.; Tan, K.; Tor, Y.; Tan, C. Chemopreventive potential of Annona muricata L leaves on chemically-induced skin papillomagenesis in mice. Asian Pac. J. Cancer Prev. 2012, 13, 2533-2539.

89. Eggadi, V.; Gundamedi, S.; Sheshagiri, S.B.B.; Revoori, S.K.; Jupally, V.R.; Kulandaivelu, U. Evaluation of anticancer activity of Annona muricata in 1,2-dimethyl hydrazine induced colon cancer. World Appl. Sci. J. 2014, 32, 444-450.

90. Hansra, D.M.; Silva, O.; Mehta, A.; Ahn, E. Patient with metastatic breast cancer achieves stable disease for 5 years on graviola and xeloda after progressing on multiple lines of therapy. Adv. Breast Cancer Res. 2014, 3, 84-87.

91. Moghadamtousi, S.Z.; Rouhollahi, E.; Karimian, H.; Fadaeinasab, M.; Firoozinia, M.; Abdulla, M.A.; Kadir, H.A. The chemopotential effect of Annona muricata leaves against azoxymethane-induced colonic aberrant crypt foci in rats and the apoptotic effect of acetogenin annomuricin E in HT-29 cells: A bioassay-guided approach. PLoS ONE 2015, 10, doi:10.1371/ journal.pone.0122288.

92. Elisya, Y.; Kardono, L.B.; Simanjuntak, P. Tablet formulation of the ethyl acetate soluble extract of soursop (Annona muricata L.) leaves. Asian J. Appl. Sci. 2014, 2, 323-329.

93. N'gouemo, P.; Koudogbo, B.; Tchivounda, H.P.; Akono-Nguema, C.; Etoua, M.M. Effects of ethanol extract of Annona muricata on pentylenetetrazol-induced convulsive seizures in mice. Phytother. Res. 1997, 11, 243-245.

94. Adeyemi, D.O.; Komolafe, O.A.; Adewole, O.S.; Obuotor, E.M.; Adenowo, T.K. Anti hyperglycemic activities of Annona muricata (Linn). Afr. J. Tradit. Complement. Altern. Med. 2009, 6, 62-69.

95. Adeyemi, D.O.; Komolafe, O.A.; Adewole, S.O.; Obuotor, E.M. Anti hyperlipidemic activities of Annona muricata (Linn). Internet J. Altern. Med. 2008, 7, 1. 
96. Florence, N.T.; Benoit, M.Z.; Jonas, K.; Alexandra, T.; Désiré, D.D.P.; Pierre, K.; Théophile, D. Antidiabetic and antioxidant effects of Annona muricata (annonaceae), aqueous extract on streptozotocin-induced diabetic rats. J. Ethnopharmacol. 2014, 151, 784-790.

97. Adeyemi, D.O.; Komolafe, O.A.; Adewole, S.O.; Obuotor, E.M.; Adenowo, T.K. Effects of Annona muricata (Linn) on the morphology of pancreatic islet cells of experimentally-induced diabetic wistar rats. Internet J. Altern. Med. 2008, 5, 2.

98. Ahalya, B.; Shankar, K.R.; Kiranmayi, G. Exploration of anti-hyperglycemic and hypolipidemic activities of ethanolic extract of Annona muricata bark in alloxan induced diabetic rats. Int. J. Pharm. Sci. Rev. Res. 2014, 25, 21-27.

99. Roslida, A.; Tay, C.; Zuraini, A.; Chan, P. Anti-inflammatory and anti-nociceptive activities of the ethanolic extract of Annona muricata leaf. J. Nat. Rem. 2010, 10, 97-104.

100. Hamid, R.A.; Foong, C.P.; Ahmad, Z.; Hussain, M.K. Antinociceptive and anti-ulcerogenic activities of the ethanolic extract of Annona muricata leaf. Rev. Bras. Farmacogn. 2012, 22, 630-641.

101. Ishola, I.O.; Awodele, O.; Olusayero, A.M.; Ochieng, C.O. Mechanisms of analgesic and anti-inflammatory properties of Annona muricata Linn. (Annonaceae) fruit extract in rodents. J. Med. Food 2014, 17, 1375-1382.

102. Chance, B.; Sies, H.; Boveris, A. Hydroperoxide metabolism in mammalian organs. Physiol. Rev. 1979, 59, 527-605.

103. Liao, J.-C.; Deng, J.-S.; Chiu, C.-S.; Huang, S.-S.; Hou, W.-C.; Lin, W.-C.; Huang, G.-J. Chemical compositions, anti-inflammatory, antiproliferative and radical-scavenging activities of Actinidia callosa var. Ephippioides. Am. J. Chin. Med. 2012, 40, 1047-1062.

104. Chen, W.; Weng, Y.-M.; Tseng, C.-Y. Antioxidative and antimutagenic activities of healthy herbal drinks from Chinese medicinal herbs. Am. J. Chin. Med. 2003, 31, 523-532.

105. George, V.C.; Kumar, D.N.; Suresh, P.; Kumar, R.A. Antioxidant, DNA protective efficacy and hplc analysis of Annona muricata (soursop) extracts. J. Food Sci. Technol. 2015, 52, 2328-2335.

106. Baskar, R.; Rajeswari, V.; Kumar, T.S. In vitro antioxidant studies in leaves of Annona species. Indian J. Exp. Biol. 2007, 45, 480-485.

107. Vijayameena, C.; Subhashini, G.; Loganayagi, M.; Ramesh, B. Phytochemical screening and assessment of antibacterial activity for the bioactive compounds in Annona muricata. Int. J. Curr. Microbiol. Appl. Sci 2013, 2, 1-8.

108. Padma, P.; Chansouria, J.; Khosa, R. Effect of alcohol extract of Annona muricata on cold immobilization stress induced tissue lipid peroxidation. Phytother. Res. 1997, 11, 326-327.

109. Padma, P.; Chansauria, J.; Khosa, R.; Ray, A. Effect of Annooa muricata and Polyalthia cerasoides on brain neurotransimitters and enzyme monoamine oxidase following cold immobilization stress. J. Nat. Rem. 2001, 1, 144-146.

110. Olakunle, S.; Onyechi, O.; James, O. Toxicity, anti-lipid peroxidation, in vitro and in vivo evaluation of antioxidant activity of Annona muricata ethanol stem bark extract. Am. J. Life Sci. 2014, 2, 271-277.

111. Nwokocha, C.R.; Owu, D.U.; Gordon, A.; Thaxter, K.; McCalla, G.; Ozolua, R.I.; Young, L. Possible mechanisms of action of the hypotensive effect of Annona muricata (soursop) in normotensive sprague-dawley rats. Pharm. Biol. 2012, 50, 1436-1441. 
112. Osorio, E.; Arango, G.J.; Jiménez, N.; Alzate, F.; Ruiz, G.; Gutiérrez, D.; Paco, M.A.; Giménez, A.; Robledo, S. Antiprotozoal and cytotoxic activities in vitro of colombian annonaceae. J. Ethnopharmacol. 2007, 111, 630-635.

113. Bories, C.; Loiseau, P.; Cortes, D.; Myint, S.H.; Hocquemiller, R.; Gayral, P.; Cavé, A.; Laurens, A. Antiparasitic activity of Annona muricata and Annona cherimolia seeds. Planta Med. 1991, 57, 434-436.

114. Ferreira, L.; Castro, P.; Chagas, A.; França, S.; Beleboni, R. In vitro anthelmintic activity of aqueous leaf extract of Annona muricata L.(Annonaceae) against Haemonchus contortus from sheep. Exp. Parasitol. 2013, 134, 327-332.

115. Ménan, H.; Banzouzi, J.-T.; Hocquette, A.; Pélissier, Y.; Blache, Y.; Koné, M.; Mallié, M.; Assi, L.A.; Valentin, A. Antiplasmodial activity and cytotoxicity of plants used in west african traditional medicine for the treatment of malaria. J. Ethnopharmacol. 2006, 105, 131-136.

116. Snow, R.; Craig, M.; Deichmann, U.; le Sueur, D. A preliminary continental risk map for malaria mortality among african children. Parasitol. Today 1999, 15, 99-104.

117. Winstanley, P. Chemotherapy for falciparum malaria: The armoury, the problems and the prospects. Parasitol. Today 2000, 16, 146-153.

118. Bidla, G.; Titanji, V.; Joko, B.; el-Ghazali, G.; Bolad, A.; Berzins, K. Antiplasmodial activity of seven plants used in african folk medicine. Indian J. Pharmacol. 2004, 36, 245-246.

119. Arthur, F.K.; Woode, E.; Terlabi, E.O.; Larbie, C. Bilirubin lowering potential of Annona muricata (Linn.) in temporary jaundiced rats. Am. J. Pharmacol. Toxicol. 2012, 7, 33-40.

120. Arthur, F.K.; Terlabi, E.O.; Larbie, C.; Woode, E. Evaluation of hepatoprotective effect of aqueous extract of Annona muricata (Linn.) leaf against carbon tetrachloride andacetaminophen-induced liver damage. J. Nat. Pharm. 2012, 3, 25-30.

121. Wezel, A.; Casagrande, M.; Celette, F.; Vian, J.-F.; Ferrer, A.; Peigné, J. Agroecological practices for sustainable agriculture. A review. Agron. Sustain. Dev. 2014, 34, 1-20.

122. Ribeiro, L.P.; Akhtar, Y.; Vendramim, J.D.; Isman, M.B. Comparative bioactivity of selected seed extracts from Brazilian Annona species and an acetogenin-based commercial bioinsecticide against Trichoplusia ni and Myzus persicae. Crop Prot. 2014, 62, 100-106.

123. Llanos, C.A.H.; Arango, D.L.; Giraldo, M.C. Actividad insecticida de extractos de semilla de Annona muricata (Anonaceae) sobre Sitophilus zeamais (coleoptera: Curculionidae). Rev. Colomb. Entomol. 2008, 34, 76-82.

124. Djamin, A.; Idris, A. Evaluation of Jatropha curcas and Annona muricata seed crude extracts against Sitophilus zeamais infesting stored rice. J. Entomol. 2012, 9, 13-22.

125. Raveloson Ravaomanarivo, L.H.; Andrianiaina Razafindraleva, H.; Raharimalala, F.N.; Rasoahantaveloniaina, B.; Ravelonandro, P.H.; Mavingui, P. Efficacy of seed extracts of Annona squamosa and Annona muricata (Annonaceae) for the control of Aedes albopictus and Culex quinquefasciatus (Culicidae). Asian Pac. J. Trop. Biomed. 2014, 4, 787-795.

126. Magadula, J.J.; Innocent, E.; Otiewo, J. Mosquito larvicidal and cytotoxic activities of 3 Annona species and isolation of active principles. J. Med. Plants Res. 2009, 3, 674-680.

127. Komansilan, A.; Abadi, A.L.; Yanuwiadi, B.; Kaligis, D.A. Isolation and identification of biolarvicide from soursop (Annona muricata Linn) seeds to mosquito (Aedes aegypti) larvae. Int. J. Eng. Technol. 2012, 12, 28-32. 
128. Grzybowski, A.; Tiboni, M.; Silva, M.A.; Chitolina, R.F.; Passos, M.; Fontana, J.D. Synergistic larvicidal effect and morphological alterations induced by ethanolic extracts of Annona muricata and Piper nigrum against the dengue fever vector Aedes aegypti. Pest Manag. Sci. 2013, 69, 589-601.

129. González-Esquinca, A.R.; Luna-Cazdres, L.; Guzmán, M.A.S.; de la Cruz Chacón, I.; Hernández, G.L.; Breceda, S.F.; Gerardo, P.M. In vitro larvicidal evaluation of Annona muricata L., A. diversifolia Saff. and A. lutescens Saff. Extracts against Anastrepha ludens larvae (diptera, tephritidae). Interciencia 2012, 37, 284-289.

130. Leatemia, J.A.; Isman, M.B. Insecticidal activity of crude seed extracts of Annona spp., Lansium domesticum and Sandoricum koetjape against lepidopteran larvae. Phytoparasitica 2004, $32,30-37$.

131. Adeoye, O.; Ewete, F. Potentials of Annona muricata Linnaeus (Annonaceae) as a botanical insecticide against Callosobruchus maculatus Fabricius (Coleoptera: Bruchidae). J. Agric. For. Soc. Sci. 2010, 8, 147-151.

132. Moghadamtousi, S.Z.; Rouhollahi, E.; Karimian, H.; Fadaeinasab, M.; Abdulla, M.A.; Kadir, H.A. Gastroprotective activity of Annona muricata leaves against ethanol-induced gastric injury in rats via Hsp70/Bax involvement. Drug Des. Dev. Ther. 2014, 8, 2099-2111.

133. Dos Santos, A.; Sant'Ana, A. Molluscicidal properties of some species of Annona. Phytomedicine 2001, 8, 115-120.

134. Moghadamtousi, S.Z.; Rouhollahi, E.; Hajrezaie, M.; Karimian, H.; Abdulla, M.A.; Kadir, H.A. Annona muricata leaves accelerate wound healing in rats via involvement of hsp70 and antioxidant defence. Int. J. Surg. 2015, 18, 110-117.

135. Paarakh, P.M.; Chansouria, J.; Khosa, R. Wound healing activity of Annona muricata extract. J. Pharm. Res. 2009, 2, 404-406.

136. Caparros-Lefebvre, D.; Elbaz, A.; Group, C.P.S. Possible relation of atypical parkinsonism in the french west indies with consumption of tropical plants: A case-control study. Lancet 1999, 354, 281-286.

137. Bonneau, N.; le Ven, J.; Schmitz-Afonso, I.; Guérineau, V.; ba Ndob, I.B.; Baloul, L.; Lewin, G.; Laprévote, O.; Brunelle, A.; Touboul, D. Annonaceous acetogenins as environmental neurotoxins: Human exposure from edible annona fruits. Planta Med. 2012, 78, PH25, doi:10.1055/s-0032-1320684.

138. Champy, P.; Melot, A.; Guérineau Eng, V.; Gleye, C.; Fall, D.; Höglinger, G.U.; Ruberg, M.; Lannuzel, A.; Laprévote, O.; Laurens, A. Quantification of acetogenins in Annona muricata linked to atypical parkinsonism in guadeloupe. Mov. Disord. 2005, 20, 1629-1633.

(C) 2015 by the authors; licensee MDPI, Basel, Switzerland. This article is an open access article distributed under the terms and conditions of the Creative Commons Attribution license (http://creativecommons.org/licenses/by/4.0/). 